\title{
Fortifying or Fragmenting the State? The Political Economy of the Opium/Heroin Trade in Shan State, Myanmar, 1988-2013
}

\author{
Patrick Meehan
}

Keywords:

Opium/heroin; Shan State; statebuilding; borderlands; militias

Professional affiliation:

Patrick Meehan is a PhD candidate in the Department of Development Studies at the School of Oriental and African Studies (SOAS). Correspondence in connection to this paper should be addressed to: patrick_meehan@soas.ac.uk

\begin{abstract}
:
Over the past twenty-five years the government of Myanmar (Burma) has consolidated control over large parts of Shan State, neutralizing much of the threat posed by armed groups and strengthening its hold over revenue extraction. During this period Myanmar has retained its position as the world's second largest producer of illicit opium, much of which is converted into heroin within the country's borders. This article explores the relationship between state-building processes and the illicit opium/heroin economy in Shan State since 1988. In doing so the article seeks to achieve four aims. First, it reassesses the theoretical assumptions that equate illicit economies with state fragility and demonstrates instead why illicit drug economies can become embedded in processes of conflict reduction and state consolidation. Second, it explains why establishing control over Shan State has become so important to the Myanmar government's state-building ambitions. Third, it analyses how the state's engagement with the drug trade has become an important part of its attempts to consolidate control, in terms of financing military expansion and brokering deals with strongmen who are able to govern local populations. Finally, the article concludes by assessing how these strategies embody a form of "negotiated statehood" in which the state's growing control has been defined by attempts to manage, rather than monopolize, the means of coercion and extraction.
\end{abstract}

\section{INTRODUCTION}

Over the past twenty-five years the Burmese/Myanmar ${ }^{1}$ state has consolidated control over large parts of Shan State, neutralizing much of the threat faced from armed groups in the region and expanding its control over revenue extraction. During this period Myanmar has retained its

\footnotetext{
${ }^{1}$ In 1989 the military government changed the official name of the country from "Burma" to "Myanmar." The change was justified by the government as means of distancing the country from its colonial past and offering a more inclusive name for both the country's Bamar majority and the multitude of ethnic nationalities within the country's borders. Many have, however, questioned this logic on both historical and linguistic grounds. The changing of the name of the country was also accompanied by name changes to other towns, cities and landmarks across the country. Rangoon, for example, was renamed Yangon, and the Irrawaddy River was renamed the Ayeyarwaddy. The names of many places throughout the country's ethnic states were also changed, replacing names which had meaning in ethnic languages with new Burman names or Burmanised version of the old names. In Shan State, for example, Kengtung was renamed Kyaingtong and Hsipaw became Thibaw. These sudden, forced changes, were viewed by many as another sign and the military's government's determination to create a single national Burman identity and its continued rejection of the 'unity in diversity' politics advocated by Aung San, the leader of the country's independence movement. Lintner 2012 offers an excellent synopsis of the issues relating to these name changes. Today, there is little uniformity regarding which names are used. Burma and Myanmar are used interchangeably whilst some of the new names have gained common parlance (for example, most people use Yangon, with Rangoon sounding increasingly anachronistic) whilst in other cases the older names are still used predominantly. I have chosen to use the term Myanmar in light of its growing usage. When citing other places which have undergone name changes I have chosen whichever name is most commonly used and will be most familiar to readers. These choices are not intended to be a political statement.
} 
position as the second largest producer of opium and has become a leading player in the global amphetamine trade. Indeed, following a period of declining production at the start of the twentyfirst century, the amount of land under poppy cultivation in Shan State more than doubled between 2006 and 2013, and the country's share of the world market of illicit opium jumped from 5 percent to 25 percent. Today Shan State accounts for over 95 percent of Southeast Asia's illicit opium, the majority of which is converted into heroin within the country's borders. ${ }^{2}$

In this article I explore the relationship between processes of state consolidation and the illicit opium/heroin economy in Shan State. ${ }^{3}$ I analyze the nature of the state's interaction with the drug trade and describe how illicit drugs have become embedded in the processes of pacification and state consolidation, which policy-makers have often assumed will reduce drug production. In doing so I make two important contributions: an in-depth empirical analysis of what I tentatively call the state-drug trade nexus in Shan State, and theoretical insights into the relationship between illicit economies and processes of state consolidation. My approach challenges dominant theoretical paradigms that have reified the linkages between drugs, instability, and state fragility and have viewed the presence of thriving drug economies as both a sign and a cause of disorder and state failure. Instead, I argue that an alternative conceptual framework is needed, one that engages empirically with the "politics of production"4 and acknowledges that the relationship between drugs, conflict, and state consolidation/breakdown is determined by the social relations surrounding production and trafficking. ${ }^{5}$

Engaging with the "politics of production" 6 in Shan State I trace three lines of enquiry that I believe have not been adequately addressed in the literature on Myanmar's illicit drug trade. The first is geographic. The political geography of Shan State has significant variation, including areas under complete government control (major towns and cities such as Lashio, Taunggyi, Hsipaw, and Kengtung), areas in which government presence is almost entirely absent (notably areas close to the China border where the government has effectively ceded control to ceasefire groups such as the United Wa State Army [UWSA], and "gray" areas in which the government's authority is contested, with the Burma Army (Tatmadaw), ${ }^{8}$ armed groups that have

\footnotetext{
${ }^{2}$ UNODC 2013.

${ }^{3}$ It is beyond the scope of this paper to address both the opium/heroin and methamphetamine trade, for whilst the political economy of the two trades share many similarities, there are also important differences. In light of the fact that a far greater number of people are involved in poppy cultivation and are reliant upon the revenue it generates, this paper focuses on analysing the political economy of opium in Shan State.

${ }^{4}$ Nevins and Lee Peluso 2008, 2.

${ }^{5}$ Meehan 2011, 402; van der Veen 2002, 104; Goodhand 2008b.

${ }^{6}$ Nevins and Lee Peluso 2008, 2.

${ }^{7}$ The UWSA was formed in 1989 after the collapse of the Communist Party of Burma (CPB). It signed a ceasefire with the Myanmar government in May 1989. It is the largest and most powerful non-state armed group in the country with an estimated 20,000-30,000 soldiers. It controls a significant area of territory in north eastern Shan State along the China border within which the Myanmar government has almost no presence. Since the mid-1990s it has also controlled a heavily contested belt of territory along the Thai-Myanmar border, often referred to as the Wa Southern Command.

${ }^{8}$ The Tatmadaw is the official name for the Myanmar Armed Forces. This term will be used throughout the piece to refer to the Myanmar Army. As will be explained later in the piece, the Tatmadaw embodies more than simply a fighting force. From the 1988 military coup until the 2010 general election, which ushered in a nominally civilian government, the Tatmadaw explicitly portrayed itself as spearheading the nation's development. At a national level the Tatmadaw portrayed itself as the primary defender of the country's Three Main National Causes, namely nondisintegration of the union, non-disintegration of nationality solidarity and perpetuation of sovereignty. At a local level, in contested 'gray' areas of Shan State - the focus of this study - the Tatmadaw represents the de facto
} 
signed ceasefires with the government, non-ceasefire armed groups, and local militias all wielding state-like powers such as tax collection, the exercise of coercive power, and the ability to manipulate the local economy. In this article I analyze the political economy of drug production in the gray areas that represent substantial parts of northern, southern, and eastern Shan State. These areas have experienced sustained expansion of poppy production over the past decade, and yet have received limited scholarly attention. Numerous studies have focused on the Wa Special Region ${ }^{9}$ (SR2) and, to a lesser extent, the Kokang and Mongla Special Regions (SR1 and SR4 respectively) ${ }^{10}$ - areas that produced the majority of Myanmar's opium throughout the 1990s - but less attention has been given to the increase in poppy cultivation in other parts of Shan State, especially following the opium bans launched in the Kokang region in 2003 and the Wa region in 2005, and the balloon effect these bans have had. Unlike in the Wa Special Region, which is administered by its own government and enjoys extensive territorial autonomy from the Myanmar government, other parts of Shan State have a heavy Tatmadaw presence. These contrasting political geographies question whether the valuable insights offered by studies into the dynamics of the drug trade in the semi-autonomous regions along the China border are representative of Shan State as a whole, revealing a significant gap in our understanding of the political economy of the drug trade in Shan State.

The second line of enquiry is temporal, focusing on the political economy of the drug trade since 1988. Some of the most fascinating insights into Myanmar's drug economy have dealt with the relationship between opium and the region's complicated ethnic insurgencies throughout the 1960s, 1970s, and 1980s. ${ }^{11}$ Whilst the drug trade continues to shape and be shaped by the war economy, the relationship between the drug trade and the political and economic changes Shan State has experienced over the past twenty-five years has received less attention. ${ }^{12}$ My research aims to address this lacuna.

The third line of enquiry examines the relationship between the illicit drug economy and the state. My goal is to demonstrate how and why the illicit opium/heroin economy has become an important foundation for attempts by the Myanmar state to pacify and consolidate control over Shan State. I argue that since the late 1980s the drug trade has offered the state an important foothold in the region. Through the engagement of state actors with the mechanisms of profitability, protection, and prosecution in the production and trafficking of drugs in Shan State, the drug trade has emerged at the apex of a dual strategy of state consolidation: (1) it has given the state a way to finance the pervasive militarization that has defined its penetration of the borderlands, and (2) it allows the state to govern through proxy authorities - predominantly local armed militia groups, often referred to as People's Militias (Pyithu Sit) —in a process of

government and has been ultimately responsible for governing these areas. Although other state institutions are present, including the police and civilian bureaucracy, these are subordinate to the Tatmadaw.

${ }^{9}$ There is no standard terminology for describing these semi-autonomous zones. After the ceasefire agreements these areas were given a temporary status of 'Special Region'. In the 2008 Constitution the term 'Special Region' was omitted, with the Wa Region instead being referred to as the Wa Self-Administered Division. In 2009 the UWSA leadership referred to the territory it controlled as the Wa State Government Special Administrative Region and has continued to demand a separate state under the Union rather than being administratively subordinate to Shan State. For the sake of simplicity I use the term Special Region.

${ }^{10}$ Ko Lin Chin 2009; Kramer 2007; Lintner \& Black 2009.

${ }^{11}$ Lintner 1999, McCoy 1999, Smith 1991, Renard 1996.

${ }^{12}$ From the outset, I want to emphasize that the intention of this line of enquiry is not to deny the perpetual involvement of insurgent groups in the drug trade, but to emphasize that focusing solely on the role played by these groups offers only a partial explanation of the political economy of drugs in Shan State. 
negotiated statehood. I show that by letting militias profit from the drug trade with impunity and by giving militia leaders political opportunities and entry into the legal economy the state has been able to forge coalitions with militia groups that manage and maintain control over local populations while remaining subservient to the military's oversight. The engagement of state actors in the drug trade in Shan State extends beyond the simplistic and normative motivations of greed and corruption and is now instrumental in state formation in Myanmar, as I will show.

The first of this article's three sections addresses the weaknesses in current conceptual frameworks of state building and the relationship between states and illicit practices. I propose alternative conceptual frameworks to define the state and to explain the role that illicit practices may play in processes of state consolidation. Section 2 contains a detailed empirical analysis of the state-drug trade nexus in Shan State since 1988, showing the central importance of the Shan borderland to state consolidation and analyzing the state's interactions with the region's illicit opium/heroin trade. The research presented here draws on interviews I have conducted in Yangon and throughout Shan State and the Thai-Myanmar borderland with poppy farmers, leaders of ceasefire and non-ceasefire groups, former militia members, community-based organizations and nongovernmental organizations (NGOs), government officials, and members of the Myanmar business community during multiple field trips to Myanmar over the past four years, including a nine-month period of fieldwork between October 2012 and June 2013. The third and final section interrogates the broader implications of the state's interaction with the illicit opium/heroin trade, analyzing how this relationship has consolidated state control, albeit in ways that remain contested and are geographically uneven.

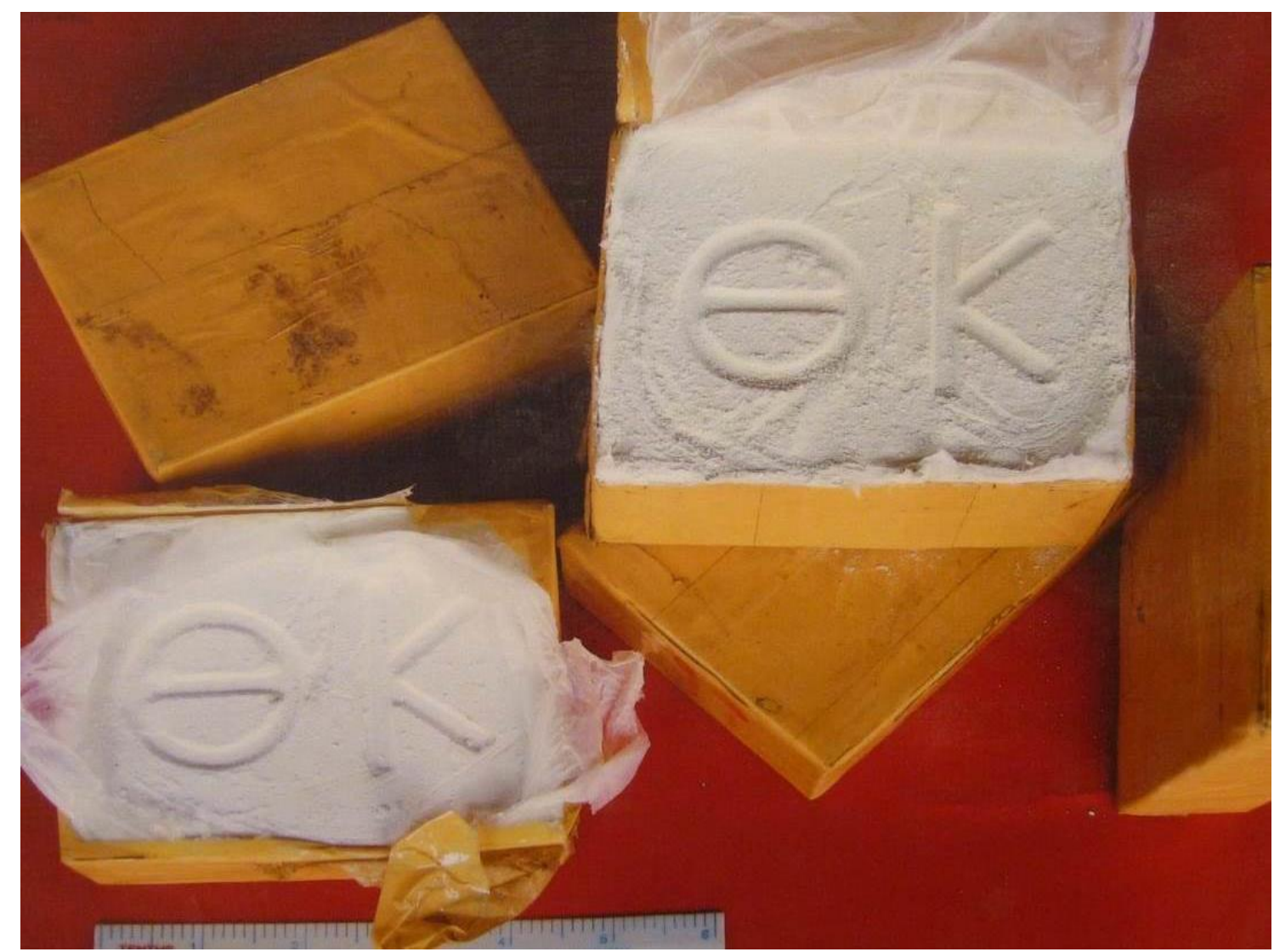

Photograph 1: Block of 'Number 4' (heroin). Photo provided to the author by a local research organisation, Taunggyi, January 2013. 
Figure 1: Shan State.

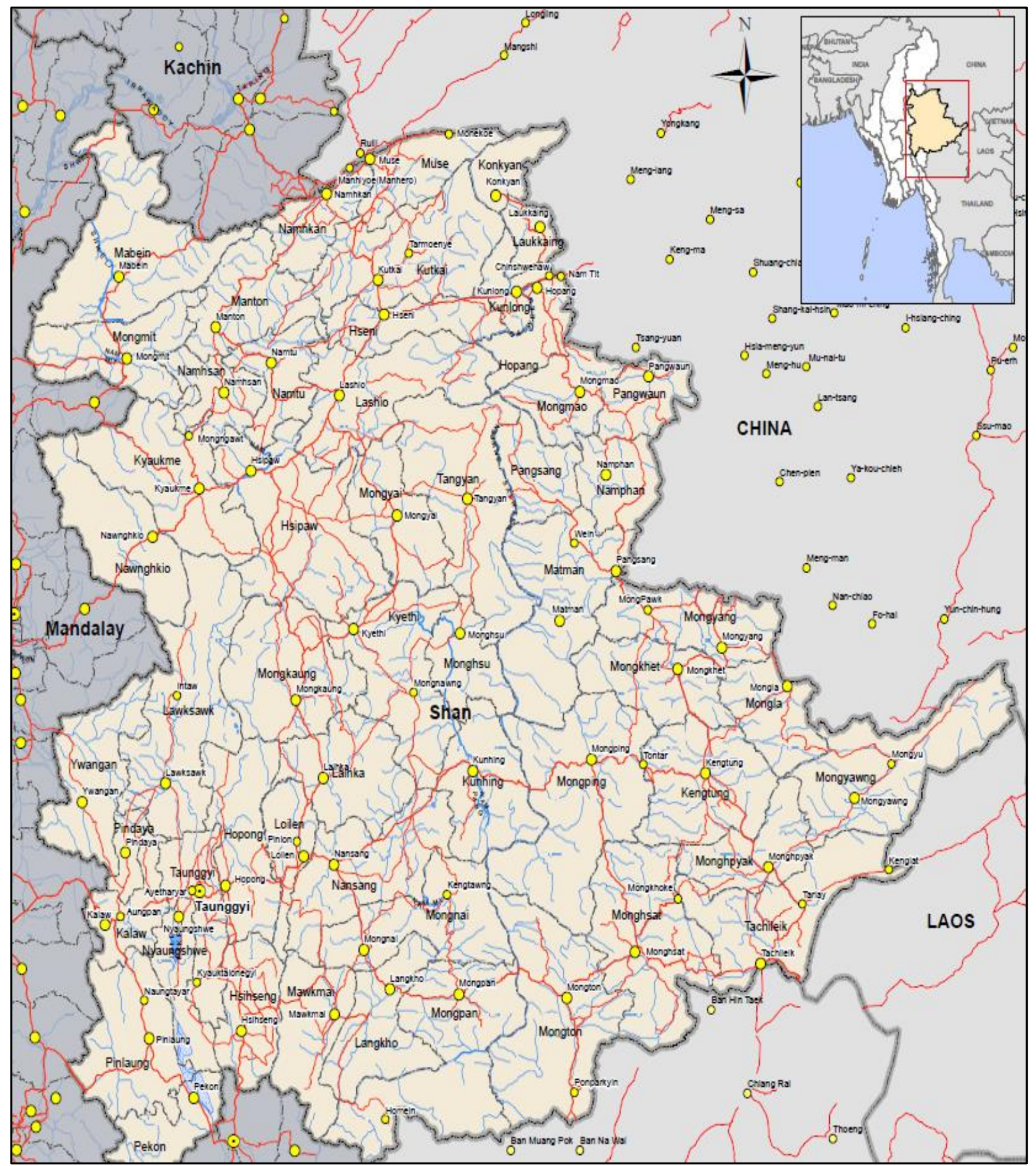

Source: Myanmar Information Management Unit (MIMU). Map ID: Map ID: MIMU696v01. Created: 14 June 2011. 


\section{ILLICIT ECONOMIES AND THE CONTESTED PROCESSES OF STATE CONSOLIDATION}

\subsection{The drugs-conflict-state fragility nexus}

The relationship between the state and illicit economies has commonly been founded upon a number of implicit "normative dualisms," "13 notably between state and non-state actors and licit and illicit activities. These dualisms equate the state with law and order and relegate illicit activities to the status of a "deviant subculture." 14 As David Nugent argues, "illegal networks are usually taken to point to the limits of the state... [and]... are generally seen to reflect and/or fill a void in state activities, to point to an absence or at least a 'thin-ness' in 'stateness'."15 Using this analytical lens is problematic, however. As Carolyn Nordstrom's work powerfully demonstrates, the artificial analytical binaries of official state-sanctioned networks versus shadow "extra-state" networks ${ }^{16}$ stunts our understanding of how states function and underestimates the significance of these networks to national and global economies. The reification of these conceptual boundaries has caused academics and policy-makers to ignore how legal and criminal goods both course through the same trade networks and have the same investors, how the same actors may navigate both networks simultaneously, and even more importantly, how extra-state networks can be an important foundation for the exercise of formal power. ${ }^{17}$ Indeed, the perception that criminal networks mark the frontier of state authority appears to reflect underlying normative assumptions about the proper role of the state, rather than being an accurate empirical analysis of the political economy of illicit commodities in source countries and of the role they play in state building and state breakdown. ${ }^{18}$

The association between illicit economies and state breakdown is also rooted in the so-called greed/grievance literature, which has focused specifically on the economic dimensions of war, especially their self-financing nature in the absence of post-cold war superpower patronage. ${ }^{19}$ Following Paul Collier and Anke Hoeffler's influential work on the relationship between resource abundance and violent conflict, analysts conceptualize most contemporary civil wars as rent-seeking predation, with the plunder of natural resources being understood as providing both the motivation to fight and the means to procure weapons and finance armies. ${ }^{20}$ Drugs in this literature have been considered an especially conflict-prone resource for a number of reasons. First, they are thought to be an inherently lootable resource: they can be extracted without the use of expensive equipment and can be smuggled easily. ${ }^{21}$ This lootability prevents states from

\footnotetext{
${ }^{13}$ Ballve 2011, 10.

${ }^{14}$ Heyman and Smart 1999, 19; Meehan 2011, 378.

15 Nugent 1999, 68-9; see also Goodhand 2008b, 413.

16 Nordstrom 2000, 36. Nordstrom chooses the term "extra-state" rather than 'non-state' or 'informal' to encapsulate the way in which "while these networks are not comprised by states themselves, neither are they entirely distinct from, or opposite to, states - they work both through and around formal state representatives and institutions."

${ }^{17}$ Nordstrom 2000, 42.

${ }^{18}$ Milliken and Krause 2002, 753-4.

${ }^{19}$ Hirshleifer 1995, 2001; Ballentine and Sherman 2003; Ballentine and Nitzschke 2005; Collier 2000; Berdal and Malone 2000; Keen 1998; Grossman 1991.

${ }^{20}$ Collier and Hoeffler 1998; Collier et al 2003.

${ }^{21}$ The extent of opium's lootability is questionable. Although no expensive equipment is needed to extract opium, poppy fields cannot simply be raided. The four-month growing season, the laborious harvesting process and the skills required to maximise yields, mean that the ability of armed groups to extract revenue from poppy cultivation is dependent less upon their ability to resort to coercion and to raid poppy sites than it is on establishing durable relationships with upland peasant communities. Although the use of coercion, in the form of threatening eradication
} 
monopolizing production or preventing extraction and, at the same time, it allows rebel leaders to provide credible material incentives for fighting, increasing soldier recruitment. Second, a thriving drug economy is deemed to require spaces that are ungoverned based on the assumption that greater state control would entail a clampdown on illegal activities depriving cross-border drug-trading networks of access to lucrative foreign markets. In its 2010 World Drug Report, the United Nations Office on Drugs and Crime (UNODC) lays out these arguments:

Large-scale opium poppy cultivation requires large land areas, and is a highly labour-intensive activity. To generate the heroin needed to satisfy global demand, thousands of hectares and hundreds of thousands of workers must be employed without state interference, and the best deterrent for state interference with this process is a rebel army. Without an active conflict, heroin production can be eliminated. ${ }^{22}$

Third, the illicit nature of drugs is assumed to make a peaceful resolution harder to achieve because the state's need to maintain legitimacy within the international system is perceived to discourage it from offering any form of negotiated settlement with rebel groups that would allow them to retain any control over the drug trade. As a consequence the opportunity cost of peace becomes extremely high for rebel groups involved in drugs. Finally, the risk premium attached to the production and trafficking of illicit narcotics makes them an especially profitable resource, increasing the likelihood that the grievances of insurgent groups may be easily corrupted. ${ }^{23}$ Analysts view the long-running insurgency in Myanmar and the activities of the FARC in Colombia as paradigmatic examples of the corruptive capabilities of drug revenues and the challenges this poses to establishing a durable peace. ${ }^{24}$ Together, liberal state-building perspectives and the greed-based analysis of contemporary conflict have encouraged policymakers to view illicit drug economies as contributing to a downward spiral of intractable conflict and ever-weakening state capacity, embodying a security threat to the West by creating ungoverned spaces in which transnational crime and terrorism are able to flourish.

\subsection{Toward an alternative political economy of drugs and state consolidation}

Empirical studies on illicit economies have presented a more complex and nuanced picture of the relationship between illicit drug production and processes of state consolidation/breakdown and (dis)order. Although illicit economies have been caricatured as motivated by greed and governed by violence, this approach ignores the extent to which these networks have developed and reproduced their own codes of conduct and institutional structures, cross-cutting national, linguistic, and ethnic divides and providing a foundation for generating stability, trust, and order. ${ }^{25}$ As Pierre-Arnaud Chouvy has rightly acknowledged, "illicit opium production largely outlasts war," with institutions involved with illicit commodities often embedding in the political and economic structures that emerge in "post"-conflict societies. ${ }^{26}$

In Myanmar's own recent history, numerous attempts have been made to harness illicit networks in an attempt to establish order and forge state-like institutions. In the mid 1960s, General Ne

and violence, plays a part in enabling armed groups to enforce taxation and to establish monopoly rights over opium sales, the relationship between armed groups and upland communities is not simply predicated upon the ability of armed groups to extract opium at gunpoint. See also, Ross 2004; Lujala et al 2005, 539; Snyder 2006.

${ }^{22}$ UNODC 2010, 232.

${ }^{23}$ Cornell 2005, 758.

${ }^{24}$ Cornell 2005; Brown 1999.

${ }^{25}$ Nordstrom 2000, 46-7.

${ }^{26}$ Chouvy 2010, xiv. 
Win sought to establish self-financing counterinsurgency militias (Ka Kwe Ye, or KKY) in the border regions by giving local armed groups permission to engage in cross-border trade, access to government-controlled roads, and legal impunity to engage in the drug trade if they agreed to disrupt the supply lines of insurgent groups. ${ }^{27}$ Recent studies have shown that the motivations for the UWSA's involvement in the drug trade extend beyond personal greed, with drug trade profits also financing its state-building efforts. ${ }^{28}$ Furthermore, the willingness of the Myanmar government to offer impunity and protection to armed groups that signed ceasefire agreements in the late 1980s and 1990s - enabling them to become heavily involved in drug production and trafficking - has challenged the notion that an active drug trade is necessarily an impediment to de-escalating conflict. ${ }^{29}$

These findings reveal the importance of developing deeper empirical analysis of the relationship between illicit economies, the construction and reproduction of power, and the forging of social order. I endeavor to demonstrate how the duality of drug production and state consolidation in Myanmar's borderlands shows that drugs should no longer be portrayed as necessarily existing only in the murky underworld of "greedy" rebels, organized crime, and terrorists operating in ungoverned spaces beyond the reach of the state; nor should they be viewed as necessarily perpetuating state fragility. An alternative conceptual framework is needed-one that is sensitive to the diversity of experiences across time and space and that engages with the "politics of production." 30 Such an approach contends that it is not the presence of illicit drug production itself, but instead the social relations surrounding production and trafficking that determines the relationship between drugs, conflict, and state consolidation/breakdown. ${ }^{31}$

\subsection{Defining state consolidation: Contestation over the resources of power}

The starting point for understanding the "politics of production" in the drug trade in Shan State over the past twenty-five years is the development of a nuanced conceptual framework for analyzing how state power is constructed and reproduced. Such a framework must engage with how states actually function, rather than how they ought to; ${ }^{32}$ it requires moving beyond the "mythicized abstraction" 33 of the state and engaging instead with its empirical reality. ${ }^{34}$ It is little exaggeration to state that Max Weber's conception of the state as "a human community that claims the monopoly of the legitimate use of physical force within a given territory" has formed the cornerstone of Western political philosophy's engagement with "the state." 35 Throughout much of the postcolonial world, however, the state has rarely been able to claim a monopoly over the legitimate use of violence or to impose its authority autonomously over society. The normative tendency in the liberal peace-building paradigm to view these shaky Weberian

\footnotetext{
${ }^{27}$ Although the KKY initiative was successful in further fragmenting the armed insurgency in Shan State, the initiative ultimately proved ineffectual as the KKY units maintained close relations with the insurgent groups whose territory their trade routes traversed. By the time the KKY initiative was abandoned in 1973 it had allowed some of Myanmar's most notorious drug lords, among them Khun Sa and Lo Hsing Han, both of whom had led KKY units, to expand the region's illicit trading networks. See: McCoy 1999: 136-8; Lintner 1984, 421-4; Lintner and Black $2009,25$.

${ }^{28}$ Kramer 2007; Ko Lin Chin 2009, 2.

${ }^{29}$ Meehan 2011, 386-91; Lintner 1993.

${ }^{30}$ Nevins and Lee Peluso 2008, 2.

${ }^{31}$ Meehan 2011, 402; van der Veen 2002, 104; Goodhand 2008b.

${ }^{32}$ Heyman and Smart 1999; Lund 2006, 674.

${ }^{33}$ Foucault 1991, 103.

${ }^{34}$ Abrams 1988.

${ }^{35}$ Weber 1919 [2004], 77-8.
} 
foundations as indicative of state dysfunction and fragility has obstructed understanding of the diversity of (often deeply illiberal) processes through which states seek to consolidate their power. Indeed, between the Kantian/Rawlian virtuous state and the Hobbesian anarchic dystopia exists a vast array of functioning state institutions. A far more interesting starting point for analysis is how states function despite lacking the institutions of Weber's ideal state. This requires conceptualizing the state as an arena, or "field of power," inhabited by diverse sets of actors and interests with competing sources of power, legitimacy, violence, and ideology and by state-like institutions that are controlled by competing social groups and not managed by a single actor, namely, the "government." 36 Key to understanding politics in Myanmar's borderlands today are questions about how state institutions are constructed, how order is institutionalized, and how revenue structures emerge in areas where the central state has no a priori monopoly over the means of violence and in which the legitimacy and exercise of public authority are dispersed and processes of state consolidation are challenged. These processes of state consolidation rely less on the specific design of state-building initiatives and more on the "shifting constellations of power that underpin formal and informal institutional arrangements" between various social actors and on how resources (political, economic, and social) are distributed as a consequence of the conflicts and coalitions involving these actors. ${ }^{37}$ It is these processes of negotiation, or negotiated statehood, that define state formation, often in ways that are unanticipated and unplanned.

In this context, state consolidation is defined by the contingent and dynamic contestation over three resources of power. The first is the competition for control over the means of coercion, which embodies the ability to enforce obedience. Rarely does this result in the monopolization of coercive power. Rather it amounts to the state's attempts to manage those able to wield power into coalition. Managing, rather than monopolizing, coercive power is an especially common and competitive process wherever popular sovereignty is contested and the repressive capacities of the state-Michael Mann's "despotic power"-are deemed essential to control populations and resources. ${ }^{38}$

Second, state-society relations in the course of state consolidation are governed by competition for revenue generation in the form of control over taxation, natural resource extraction, and trade. Wherever the state's writ is weak and contested, state actors have incentives to control and expand revenue extraction, including financing the expansion of the state's coercive powers (army and police) and its legibility and iconography (administrative structures such as border checkpoints), attempts to deny those opposing state authority access to revenue flows, and strategies designed to direct revenue flows to the center. State actors may also seek to direct revenue to create what Douglass North et al. have described as "limited access orders" in which powerful non-state actors are given access to valuable political and economic rents in an attempt to "buy" their loyalty and encourage them to cooperate with the state rather than to challenge it."

\footnotetext{
${ }^{36}$ Migdal 2001, 15.

${ }^{37}$ Di John 2008: 35.

${ }^{38}$ Mann 1984. “despotic power” embodies the state's abilities to impose forcible control 'over society' and represents the repressive capabilities of the state. Mann contrasted this with the exercise of "infrastructural power" which represents the state's power to penetrate society and implement its decisions. It is seen to require a degree of cooperation and engagement between rulers and citizens with the state governing 'through society'.

${ }^{39}$ North et al 2007; North et al 2009.
} 
Third, state consolidation is shaped by the contest over the very legitimacy of state power. Henri Lefebvre's assertion that the modern state is a form of "violence directed towards a space,"40 designed to create a unified and homogenous society in a space that "has nothing homogenous about it," 41 is a powerful corrective to state-centric analysis and captures the essence of how the struggle for legitimacy is a contested process in which the state has to wrestle support away from other social actors. The quest for political legitimacy is founded in the state's desire to make societies and cultures more easily "legible" and "governable" in order to control populations and impose regularized systems of taxation and land ownership. ${ }^{42}$

\subsection{The spatial dynamics of state consolidation: Borderlands and illicit economies}

The dynamics of borderlands pose a specific set of challenges to the construction and legitimation of state power. James C. Scott's conceptualization of borderlands in Southeast Asia as zones of hybridity and resistance provides the clearest insight into the historic challenges the state has faced in these spaces. He argues that Southeast Asian borderlands are zones of refuge, or "shatter zones," defined by activities and ideologies designed explicitly to repel the centripetal forces of the state's "civilizing mission." these zones - low population density, extensive agriculture, and linguistic and ethnic diversityis a response to the state's efforts to control them. It is also in the borderlands, where identities and affiliations straddle cartographic boundaries, that the state's efforts to create a territorially defined nation state may be revealed most starkly as illusory. ${ }^{44}$ This is especially common in the postcolonial Global South, where "most states are 'younger' than the societies they purport to administer and the demarcation of borders preceded nation-building." 45

The extent to which borderland regions such as Shan State can be understood as continuing to repel state encroachment has been increasingly questioned. Scott himself has argued that in light of the growing military and technological capabilities of the state throughout the twentieth century his analysis is applicable only to the pre-World War II period. Furthermore, the postcold war emphasis on regional economic integration as a tool for development has transformed the perception of many borderlands from frontier regions or buffer zones to economic corridors that encourage states to invest resources in consolidating control over these remote areas. ${ }^{46}$

However, the rhetoric promoted by states, international financial institutions, and regional economic bodies about the expansion of territorial control and economic integration in borderland regions must also be questioned. Neil Brenner rightly argues that the extension of territorial control is "represented as a natural precondition of social and political existence rather than being seen as a product of historically determinate strategies of parcelization, centralization,

\footnotetext{
${ }^{40}$ Lefebvre 1991, 280.

41 ibid, 308.

${ }^{42}$ Scott 1998.

${ }^{43}$ Scott 2009, 325.

${ }^{44}$ Appadurai 2001, 7-8.

${ }^{45}$ Goodhand 2008a, 228.

${ }^{46}$ Notable examples include (i) India's Look East policy in which Northeast India has come to be viewed as an important gateway to economic integration with southeast Asia; (ii) the Asian Development Bank-funded Greater Mekong Sub-Region (GMS) initiative designed to stimulate trade between Thailand, Laos, Cambodia, Vietnam, Yunnan Province (China) and Myanmar by establishing 'economic corridors' which now traverse through regions, such as Shan State and parts of northern Laos, over which central governments have historically commanded little authority. (Swe \& Chambers 2011, 6).
} 
enclosure, and encaging. "47 As Brenner warns, the aim of these narratives is to shroud the violence, contestation, and subversion that underpin these processes and project instead state power and legitimacy over areas where state authority is anything but hegemonic. Indeed, there remains much validity to Scott's assertion that the exercise of state authority in borderland regions continues to be undermined by the fact that the state is confronted with preexisting structures of power relations and alternative forms of existing public authority that feel threatened by, and are likely to try to repel, state encroachment. This viewpoint is also reflected in Catherine's Boone's analysis of the political topography of the African state and her emphasis on how the state's interaction with its rural peripheries is rarely determined exogenously (by ideology, centrally planned strategies, or the demands of international donor institutions). Rather it is shaped by the existing rural structures and hierarchies with which the state is confronted. ${ }^{48}$ Borderlands thus bring into focus the perpetual struggle that state actors face between the assertion and legitimation of state power and more pragmatic strategies that are "forced to work with the grain of society." 49

The dynamics of illicit borderland economies cannot be abstracted from these contested processes of state consolidation. In many locations, including Shan State, illicit economies have a much longer history than the state itself. The state is therefore navigating an environment in which preexisting structures of authority are powerful and in which, in the case of Shan State, the drug trade has become the foundational pillar of local power structures. The super-rents made possible due to the risk premium attached to drug production gives those able to tax and trade drugs a way to generate capital, develop cross-border networks, generate the funds necessary to arm and retain soldiers, and ultimately establish patronage networks to induce loyalty and extend control over resources and populations. It is thus not surprising that processes of state formation are commonly defined by attempts to harness the relationship between drugs and power rather than to dismantle this relationship.

The state's engagement with illicit borderland economies may be a recent phenomenon, but state actors control mechanisms that can be used to maximize drug rents. These include offers of official protection and impunity, money laundering services, the ability to convert power and revenue generated through illicit networks into formal authority and legal enterprises, and sanctioning the right to use violence. By selectively distributing these opportunities the state positions itself to build political coalitions, embodying a form of negotiated statehood, and a means through which to stabilize its authority in borderland regions over which it has wielded little authority. As I show below, understanding how the opium/heroin trade in Shan State has become deeply embedded in the construction of state power shows why drug production and trafficking has continued even as many drug-producing regions have come under state control.

\footnotetext{
${ }^{47}$ Brenner 1999, 49. For a further critique of the depoliticisation of processes of territorialisation see: Agnew and Corbridge 1995, 78-102; Baud \& Schendel 1997; Goodhand 2008a; Agnew 2008, 180; Newman and Paasi 1998, 196.

48 Boone 2003.

${ }^{49}$ Goodhand 2013, 256.
} 


\section{REASSERTING THE STATE AND THE EMERGENCE OF THE STATE-DRUG TRADE NEXUS}

\subsection{The Shan State borderlands as a "neuralgia point" of the postcolonial state}

The troubled relationship between the central state and the borderlands is one of the defining features of postcolonial Myanmar. The very birth of independence was reliant upon Aung San's ability to demonstrate to the British a workable solution to unifying the country. This required incorporating into the postcolonial nation the "Frontier Areas", which had been governed directly by the governor of Burma as distinctly separate areas from "Burma Proper" and had limited interaction with the colonial government. ${ }^{50}$ The Panglong Agreement, signed by Aung San and Shan, Kachin, and Chin representatives, created the foundation for a unified Burma and has been part of the contested iconography and ideology of the postcolonial state and borderland populations ever since. ${ }^{51}$ The unresolved issues of power distribution between center and margins and the constitutional contestation over questions of federalism have shaped the mentalities of both the central government and opposition groups in the borderlands for the past seven decades. The 1962 military coup was inspired by fears that tensions in the country's borderlands "threatened to bring about the state's disintegration," 52 while the militarization of the authoritarian state under General Ne Win's nationalist ideology of "one blood, one voice, one command," was a response to the subversion of these ideas by borderland populations and armed groups fighting against the government. ${ }^{53}$

The capacity of the Shan State borderlands to be a neuralgia point for the postcolonial state was reflected in the way the region's dense forests and rugged hills became a refuge for opposition forces. During the 1950s this was seen in the difficulties the government faced expelling the Chinese Kuomintang (KMT) forces - which had fled across the border from Yunnan Province after the end of the Chinese Civil War and who were using Shan State as a base from which to attempt to re-invade China-and in the fears that their presence would incite a Chinese invasion. ${ }^{54}$ During the long-running insurgency campaigns against the central government after independence, the Shan State borderlands became home to the Communist Party of Burma (CPB) and other armed groups, some of which were backed by neighboring countries with a vested interest in preventing the Myanmar state's encroachment up to the region's porous borders. The government's struggle to assert control, often violently through military-led counterinsurgency campaigns (including the notorious Four Cuts Campaign, which tried to break the links between insurgents ${ }^{55}$ and local populations and so deprive resistance groups of access to recruits, food, finance, and intelligence) has made local populations wary about state encroachment, which they have invariably experienced as military abuses, forced labor,

\footnotetext{
${ }^{50}$ Maule 1993.

${ }^{51}$ Walton 2008, provides a detailed analysis of the events surrounding the Panglong agreement and its enduring legacy.

52 Brigadier General Aung Gyi, cited in Sai Aung Tun 2009, 492.

53 This nationalist ideology originated out of the earlier Dobama Asiayone independence movement of the 1930s which took as one of its mottos "One party, one blood, one voice, one command" (Smith 2002, 273).

${ }^{54}$ Gibson 2011.

55 Many armed groups reject the term "insurgent", preferring instead to define themselves as "resistance" groups. They argue that the term "insurgent" reflects the reification of the state in political analysis and policymaking because it confers legitimacy upon the state and characterizes the actions of those opposing the state as illegal. My decision to use the term "insurgent" is not intended to be a political statement on the relative legitimacy of those involved in Myanmar's conflict.
} 
expropriation of property, taxation, and intolerance of cultural diversity. This environment strengthened local strongmen and armed groups who proved able to hold the state at bay. By the 1980 s, the Shan State borderlands were a complex "field of power" marked by intense contestation over the three power resources that govern state-society relations: a multitude of armed groups were undermining the central government's struggle for control over the means of coercion; opium production and opposition forces' control over the country's flourishing black market cross-border trade created lucrative revenue streams beyond the control of the government; and ethno-nationalism and demands for a federal constitution became powerful counter-narratives to the government's own efforts to forge popular sovereignty under a centralized unitary state.

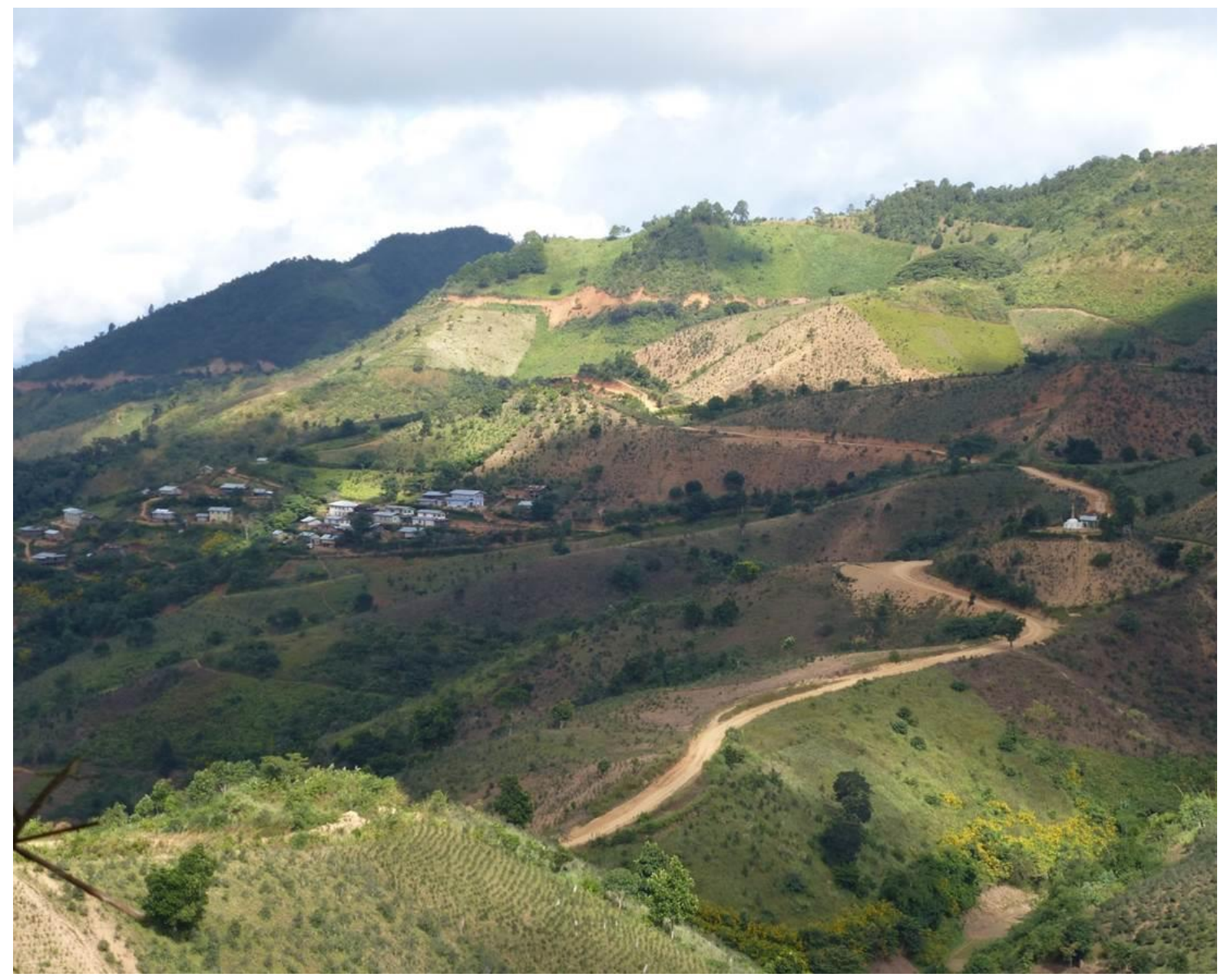

Photograph 2: Rural southern Shan State. Photograph by the author, Kalaw, December 2012.

\subsection{Myanmar's changing political geography post-1988: The centrality of the Shan State borderlands}

By the late 1980s Ne Win's state-building strategies were failing. Chronic economic mismanagement had left the state close to bankruptcy; insurgency was rife throughout the country's borderlands despite decades of brutal counterinsurgency offensives; and widespread pro-democracy protests in 1988 demonstrated that the government was losing support in the core of the country. The emergence of Aung San Suu Kyi and the National League for Democracy (NLD) showed a credible opposition seemingly able to win support across ethnic groups, as 
evidenced by the party's landslide victory in the 1990 election. However, new opportunities for state-building were also emerging, due to a constellation of shifting political, economic, and social dynamics that reshaped the Shan State border world. The State Law and Order Restoration Council (Slorc) — the military government that had replaced Ne Win's ailing Burma Socialist Programme Party (BSPP) — was quick to exploit this situation. ${ }^{56}$

Within months of the state's brutal repression of the 1988 pro-democracy demonstrations, the $\mathrm{CPB}$, the country's largest insurgency group, collapsed and divided into four separate armies, the largest of which was the UWSA. ${ }^{57}$ Alongside the disarray caused by the CPB's collapse, the changing attitude of Myanmar's neighbors also furthered the Slorc's state-building agenda. Under Deng Xiaoping, Chinese patronage of the CPB was terminated as China began to regard Myanmar as a potentially useful economic ally. China coveted Myanmar's natural resources in order to fuel its industrial economy. Beijing also viewed cross-border trade as a cost-effective way to ameliorate China's coast-interior divide by stimulating economic development in landlocked Yunnan Province. Access to the Bay of Bengal through Myanmar was envisioned by the Chinese government as an opportunity to reduce its strategic vulnerability (caused by its reliance on the Malacca Straits) and to enable it to fulfill its "two ocean" policy by giving it an opening to the Indian Ocean. In Thailand calls to improve political and economic relations with Myanmar were growing as part of Thailand's efforts to convert mainland Southeast Asia "from sanam rop (battlefields) to sanam kankha (marketplaces)" - a strategy Thailand believed would make it the predominant merchant state in the region. ${ }^{58}$

For political and economic reasons, control over the country's eastern and southern borderlands gave the state a new opportunity to consolidate by capitalizing on the disarray caused by the collapse of the CPB and to gain control over the region's resources and border trade in order to improve its financial position. The Slorc reacted quickly to these emerging opportunities, reaching verbal ceasefire agreements with all four CPB splinter groups by June 1989, as well as the Shan State Army (SSA) in September $1989,{ }^{60}$ and the Kachin Defence Army, ${ }^{61} \mathrm{~Pa}-\mathrm{Oh}$ National Organisation, and Palaung State Liberation Army in 1991. ${ }^{62}$

\footnotetext{
${ }^{56}$ In 1997 the SLORC was renamed the State Peace and Development Council (SPDC).

${ }^{57}$ Lintner 1990. The four CPB splinter armies were the United Wa State Army (UWSA) located in the Wa Hills east of the Salween River, the Myanmar National Democratic Alliance Army (MNDAA) which controlled the Kokang area of northern Shan State, the National Democratic Alliance Army (NDAA: formerly Shan State Army-East (SSA-E) headquartered at Mongla on the China border, and the New Democratic Army-Kachin (NDA-K) based close to the Chinese border in Kachin State.

58 Thant Myint-U 2006, 287, 308; Renard 1996, 108.

${ }^{60}$ The Shan State Army (SSA) had been heavily reliant upon the CPB for supplies, especially ammunition. The SSA became known as the Shan State Progress Party/Shan State Army (SSPP/SSA) in 1996. Following the surrender of Khun Sa's Mong Tai Army, approximately 3,000 troops refused to accept surrender. Under the leadership of Yawd Serk they initially reformed as the Shan United Revolutionary Army (SURA) before renaming themselves the Shan State Army (SSA). To avoid confusion between the two groups, the SSPP/SSA is commonly referred to as the SSA'North', whilst Yawd Serk's troops, headquartered on the Thai-Shan border at Loi Tai Leng have been referred to as the SSA-'South'. In May 2000 the SSA-'South' formed its political wing the Restoration Council of Shan State (RCSS). The SSA-'South' signed a ceasefire with the government in December 2011.

${ }^{61}$ The KDA is led by Mahtu Naw, who was a former Commander of the Kachin Independence Army's (KIA) Fourth Brigade. He became leader of splinter group the Kachin Defence Army in 1990, signing a ceasefire agreement with the SPDC in 1991. It seems that after the KDA split from the KIA it was allowed to maintain barracks, troops and weapons by the Tatmadaw.

${ }^{62}$ Meehan 2011, 388.
} 
The surprise surrender of Khun Sa's Mong Tai Army (MTA) in 1996 further transformed the situation in Shan State. The MTA was formed in 1985 out of Khun Sa's Shan United Army (SUA) and by the early 1990s controlled most of the Thai-Shan border. However, the stability afforded by the ceasefire agreements that the government reached with the former CPB splinter groups enabled the Tatmadaw to concentrate its forces against the MTA and other groups that had refused to sign a ceasefire, notably the Karen National Union. By 1996, although still a significant fighting force of approximately 10,000 soldiers, the MTA had suffered heavy losses at the hands of joint military offensives by the Tatmadaw and the UWSA, which had been sanctioned to move troops down to the Thai-Shan border from its heartlands around Panghsang in northeastern Shan State. Furthermore, the Thai authorities' decision to cooperate with the Burmese government against Khun Sa by closing the Thai border denied his army access to vital cross-border supplies of rice. ${ }^{63}$ Faced with a major internal rebellion, predominantly from among Shan soldiers who resented Chinese dominance within the MTA's leadership, Khun Sa sued for peace. Aware of the case of Panama's Manuel Noriega ${ }^{64}$, Khun Sa had also become fearful of U.S. indictment and in return for official protection he agreed to surrender, moving to Yangon where he invested in numerous legal enterprises. ${ }^{65}$ The surrender of the MTA, which at one time controlled territory as far north as Loilem and had monopolized trafficking routes into Thailand, had a profound impact on both the political situation and the drug trade in Shan State.

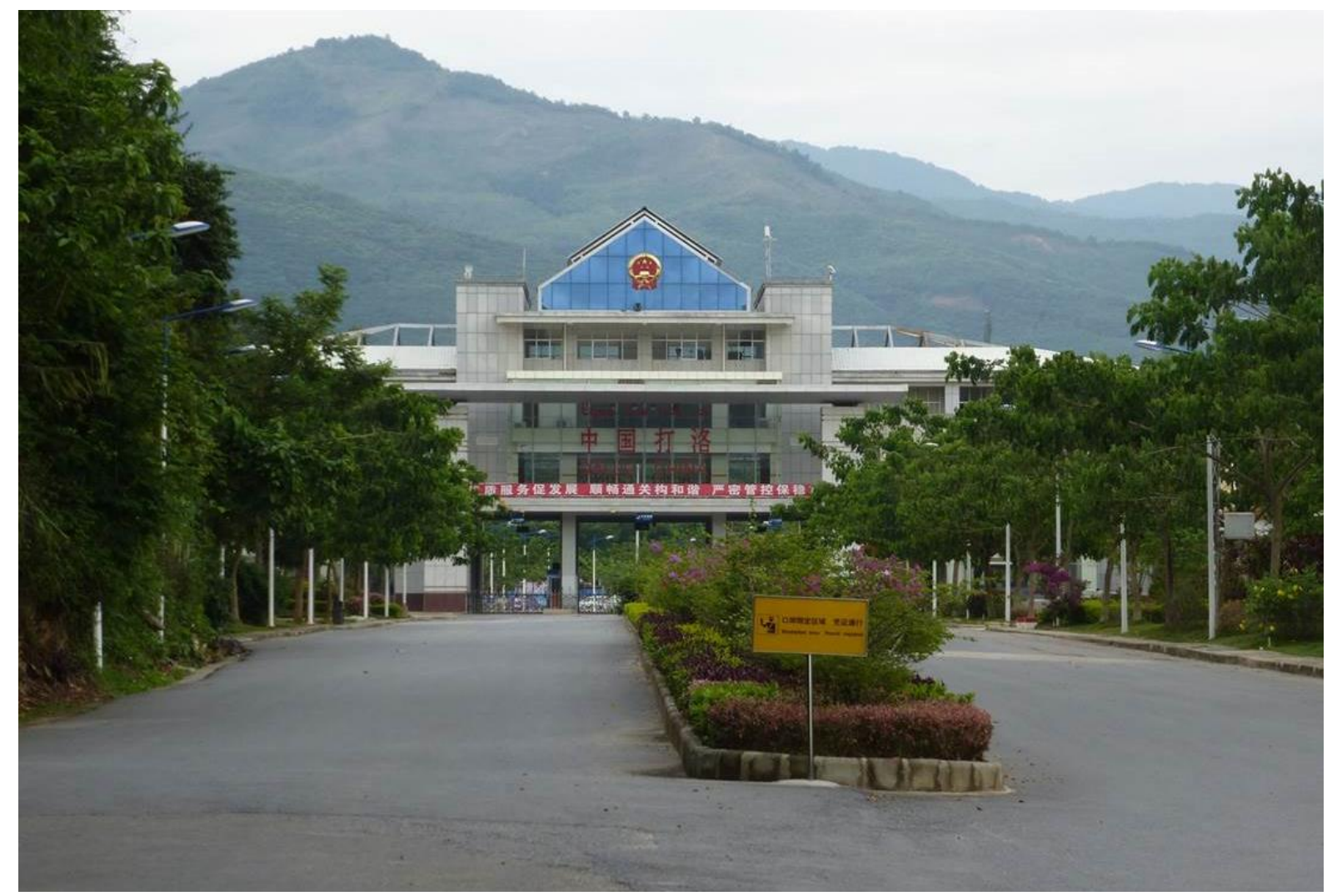

Photograph 3: Myanmar-China checkpoint in Mong La, Special Region 4. Photograph by the author, May 2013.

\footnotetext{
${ }^{63}$ Interview with former MTA member. 27 April 2014. Fang (Chiang Mai Province).

${ }^{64}$ Manuel Noriega was the military dictator of Panama from 1983 to 1989 . Following a US invasion of Panama in 1989 - Operation Just Cause — Noriega was removed from power and sentenced to fifteen years imprisonment in the US on drug trafficking and money laundering charges.

${ }^{65}$ Interview with former MTA member. 29 April 2014. Chiang Mai.
} 
The ceasefire agreements and the MTA's surrender marked a decisive shift in the dynamics of Shan State. A "kind of post-civil-war-not-quite-peace environment" ${ }^{\text {"66 }}$ emerged, defined by the declining strength of non-ceasefire armed groups and the renewed determination of the central government to pacify, control, and extract revenue from the borderlands. The Myanmar state, once a weak and marginalized player kept at bay by armed groups and its own limited financial and military resources, has become able to exert its influence. As I explain below, the state's consolidation over the past quarter century has rested on the foundation of its interactions with the opium/heroin trade in Shan State.

\subsection{The state-drug trade nexus, $1988-2013$}

As the state began to assert greater authority across Shan State, the borderland it faced was less the wild, anarchic space or "institutional tabula rasa" ${ }^{\text {"67 }}$ of popular imagery and more a region governed by well-established local power structures, albeit structures that were complex and volatile due to the multitude of armed groups operating there. In a region of protracted conflict, poverty, underdeveloped agriculture and industry, and poor infrastructure, opium has emerged as a commodity success story in Shan State over the past sixty years, thanks to the qualities intrinsic to it. These include its guaranteed market, its low bulk and limited spoilage (reducing the pressure to reach markets quickly), its ability to generate more income than other cash crops grown in the area, the access to credit it offers, and the fact that it grows well even on steep, infertile land and with minimal inputs (other than labor). By the late 1980s the drug trade had become one of the foundational pillars of local power structures, generating revenue through taxation and trade, establishing cross-border trade networks, and offering a way (often the only way) to accumulate capital and generate the money needed to arm and retain soldiers. With limited finances, military, and administrative manpower, and lacking popular legitimacy, state actors have extended and entrenched their authority across Shan State by manipulating and reshaping the relationship between opium and power. Rather than using their newfound authority to curtail or dismantle the region's illicit drug production networks, they have used the drug trade to fulfill their state-building objectives.

The government has followed two clear strategies in consolidating its control in Shan State: increasing its physical presence and coercive power across the region through a concerted process of military expansion, and engaging in a form of "negotiated statehood" by creating forms of local governance - either by strengthening preexisting structures of authority or establishing new structures - that manage and maintain control over local populations while remaining subservient to the Tatmadaw's oversight. These forms of "extra-state" governance have strengthened the government's control over rural areas and insulated the Tatmadaw from the rigors and risks involved in the every-day governance of these areas. The government's interaction with the region's illicit drug trade has become an integral part of operationalizing both these strategies.

\subsection{Drugs and militarized state consolidation}

The Tatmadaw, whose privileged position in the country is enshrined in the 2008 constitution, views itself as the cornerstone for preserving the country's sovereignty and spearheading its development. Over the past twenty-five years the government has invested heavily in the Tatmadaw, with military spending accounting for an estimated 30-50 percent of the annual

${ }^{66}$ Callahan 2007a, xiv; TNI 2009.

${ }^{67}$ Zeller 2013, 195. 
national budget. ${ }^{69}$ In recent years the defense budget has fallen, although for the 2013/4 fiscal year it still amounted to over US $\$ 2$ billion, or approximately 20 percent of the national budget, the highest of any Asean country. ${ }^{70}$ Alongside the official budget there exists the so-called Special Funds Law promulgated on 17 January 2011, which provides the commander-in-chief of the Tatmadaw access to unlimited funds deemed necessary to preserve national security, without parliamentary scrutiny. ${ }^{71}$

As Andrew Selth, one of the leading analysts of the Tatmadaw, explains, a clear rationale underlies the government's heavy military expenditure:

The Rangoon regime envisage[d] a permanent military presence in almost every part of the country. In the past, Burma's lack of financial and military resources had meant that large tracts of territory were effectively beyond the government's control.... The central government's writ ran when there was a military presence, but the army was spread very thinly.... A permanent presence throughout Burma would give the Rangoon regime a number of direct benefits. It would permit the Tatmadaw to monitor political and military developments in the frontier districts more closely, exercise greater administrative control over those areas, better regulate cross-border traffic and improve revenue collection... The expansion of the Tatmadaw is also linked to the regime's economic ambitions. Without the means to crush future political unrest, it cannot establish and maintain the kind of internal stability which it believes is necessary to encourage foreign investment and economic growth. Also, without a much larger army, the regime does not feel confident that it can protect the newly restored overland trade routes through the troubled border regions of China, Thailand and India. ${ }^{72}$

The government has three reasons for wanting to establish a comprehensive military presence in Shan State: combating the ongoing insurgency in the state; establishing control over the state's coveted natural resources and cross-border trade; and encouraging local populations to comply with government authority. A 2007 survey estimated that over one quarter of the entire Tatmadaw is based in Shan State; eighty-nine infantry or light infantry battalions operate in southern Shan State alone. ${ }^{73}$ A strong military presence allows the government to launch offensives against armed groups that have refused to sign ceasefire agreements and to encourage ceasefire groups and militias to find accommodation with the government rather than challenge its growing presence in the borderlands.

The military presence also allows the state to control the means of extraction. In northern Shan State, at least twenty-six Tatmadaw infantry units have been deployed across six townships to protect the route of the oil and gas pipelines that the China National Petroleum Company is constructing in a joint venture with the Myanmar government to deliver offshore crude oil and natural gas from the Bay of Bengal to China's Yunnan Province. In many villages along the route, police, Tatmadaw soldiers, and militia members work alongside each other. ${ }^{74}$ The gas

\footnotetext{
${ }^{69}$ For decades the Tatmadaw has been extremely secretive about its spending and there are no reliable figures available for levels of defence spending. Myanmar is one of only a handful of countries for which the Stockholm International Peace Research Institute (SIPRI) military expenditure database offers no data at all, reflecting these difficulties. According to David Steinberg (2001, 78), the Myanmar government stated that for the 1997/8 fiscal year almost one third of the entire national budget was allocated to the Tatmadaw, whilst many analysts believe defense spending over the past twenty-five years has been closer to 40 percent of the national budget.

${ }^{70}$ Naw Noreen 2014.

${ }^{71}$ Cheesman et al 2012, 147; Wai Moe 2011.

72 ibid, 36.

73 TBBC 2007, 81.

74 TSYO 2012, 26.
} 
pipeline became fully operational in July 2013 and in its first year channeled almost 2 billion cubic meters to China. Over the next thirty years this pipeline will generate an estimated $\$ 30$ billion for the Myanmar government. ${ }^{75}$ In eastern Shan State the number of battalions based across Kengtung, Mongphyak, Tachilek, and Mongyawng townships increased from six in 1988 to thirty-four in 2006, reflecting the strategic importance of an area through which the 275kilometer Route 3B road passes, linking Tachilek on the Thai-Myanmar border with Mongla on the China-Myanmar border. ${ }^{76}$ The Mekong River also flows through this region, forming the 234-kilometer border with Laos. Both the river and road network form a major part of the Asian Development Bank's “North-South Economic Corridor” initiative to link the region's economies. The militarization of this remote corner of eastern Shan State demonstrates the government's determination to create a stable and peaceful economic environment in order to encourage more Thai-China trade to use Route $3 \mathrm{~B} .{ }^{77}$

Generating greater collaboration and compliance from local populations is another aim of the Slorc/SPDC military buildup. Stathis Kalyvas's convincing analysis of the dynamics of "irregular war" emphasizes "the role of control in shaping civilian collaboration. A key point is that control-regardless of the "true" preferences of the population-precludes options other than collaboration by creating credible benefits for collaborators and, more importantly, sanctions for defectors." ${ }^{78}$ Kalyvas argues that "military resources generally trump the population's prewar political and social preferences in spawning control." ${ }^{, 79}$ The fundamental logic of establishing "geographical loyalty," namely, that territorial control will generate compliance and, ultimately, acceptance, embodies the very foundation of the Myanmar government's attempts to consolidate control throughout the country's borderlands. ${ }^{80}$ This logic has negated the Tatmadaw's belief that a political settlement is not necessary to generate stability.

Post-1988 attempts to strengthen the Tatmadaw in the borderlands have been financed only partly by the central government. Instead, the Tatmadaw has been required to "live off the land" in line with a policy that became explicit in 1997 when the government's War Office informed the Tatmadaw's twelve regional commanders that troops "were to meet their basic logistical needs locally, rather than rely on the central supply system." ${ }^{81}$ Dry rations provided to soldiers by the central government decreased significantly as a result. ${ }^{82}$ Living off the land had been an unofficial policy during the Tatmadaw's counterinsurgency activities throughout the 1960s, 1970s, and 1980s, but the growth in the number of military personnel deployed in the borderlands and the fact that the Tatmadaw became directly responsible for governing these regions greatly increased the need to generate more revenue locally.

The 1988 military coup and the collapse of Ne Win's BSPP established the military as the sole political authority across the country with significant power and autonomy given to regional commanders. Central party committees were dismantled and BSPP-managed People's Councils were abolished and replaced at the local level by Tatmadaw-controlled Law and Order

\footnotetext{
75 TSYO 2012; SGM 2011a; SGM 2011 b.

${ }^{76}$ LNDO 2006, 8.

${ }^{77}$ Swe and Chambers 2011, 26; 35-36; 113-4.

${ }^{78}$ Kalyvas 2006, 145.

${ }^{79}$ ibid, 111.

${ }^{80}$ Seidman 2002, 40, cited in Kalyvas 2006, 113.

${ }^{81}$ Selth 2002, 136; Callahan 2007b, 46.

${ }^{82}$ Maung Aung Myoe 2009, 170.
} 
Restoration Councils (later Peace and Development Councils). The Tatmadaw acts as the de facto local government in the contested gray areas of Shan State. Beyond its military duties, it manages and is responsible for financing all local administration (including police and law enforcement), regulating the local economy, and overseeing the local activities of numerous government departments, notably the Central Committee for Drug Abuse Control (CCDAC) and the Central Committee for the Development of Border Areas and National Races (often referred to as $\mathrm{Na} \mathrm{Ta} \mathrm{La).}$

This near autonomy, coupled with the ever-pressing need to combat insurgent groups and expand the size of the Tatmadaw, required regional and battalion commanders to generate greater revenue with little scrutiny (or concern) for how this was achieved.

As Maung Aung Myoe explains,

the problem with military activities came with the decentralization of command and concentration of ministerial authorities in the hands of regional commanders in 1988, which opened up opportunities for regional commands to engage in various businesses.... Moreover, the growing prices of consumer goods pushed the Tatmadaw to seek off-budget external income to finance its welfare activities at the regional and local levels. Initially, only the command headquarters level engaged in business. Later, all local military units commanded by either the Commanding Officer (CO) or the Officer in Command (OC) were allowed to do business in the name of welfare. All $\mathrm{COs}$ and OCs were forced to find external income to finance welfare activities to pay monthly cash subsidies for the troops.... The Tatmadaw's businesses served as instruments for political patronage and economic rent-seeking. At the same time, these commercial enterprises provided financial assistance to cushion up the budgetary constraints on defence expenditure, and contributed to the welfare and well-being of the Tatmadaw's personnel and their families. ${ }^{83}$

In order to generate revenue the Tatmadaw has built coercive and extortionate structures of informal taxation throughout Shan State. These encompass heavy taxation on crops, livestock, land, vehicles, travel (in the form of tolls), shops, and small-scale businesses, and the forced purchase of goods (primarily rice) at below-market prices. In the words of one Shan researcher, "people are quite literally paying the price of the government's militarization strategy." ${ }^{84}$ Not surprisingly, the Tatmadaw has also used its power in the region to derive revenue from the lucrative and well-established drug trade across Shan State. That this fact remains widely unacknowledged reflects Unodc's compromised position ${ }^{85}$ — and its subsequent failure to inform on this issue - and the reluctance of analysts to engage with the findings of border-based

\footnotetext{
${ }^{83}$ Maung Aung Myoe 2009, 190.

${ }^{84}$ Interview with Shan researcher. 12 November 2012. Chiang Mai.

85 The Unodc's ability to operate in the country and to conduct field surveys is dependent upon maintaining the support of the government. Yet, according to a former UN employee interviewed in Yangon (interviewed on 11 June 2013), the Unodc has little support within the Ministry of Home Affairs. Unodc data draws heavily upon data provided by the Myanmar government's Central Committee for Drug Abuse Control (CCDAC), the reliability of which is highly questionable (see: PWO 2010, 36). For example, the 2013 Southeast Asia Opium Survey explicitly acknowledges that the Unodc "did not monitor or validate the results of the eradication campaign carried out by the Government of the Republic of the Union of Myanmar (GOUM)," yet continued to cite government figures on eradication throughout the report (Unodc 2013, 76). Reports consistently avoid the issue of taxation of opium and have continued to blame resurgent production on non-state actors. For example, in 2008, the Unodc stated that its annual "survey found that opium poppy cultivation took place in areas controlled by insurgency and by ceasefire groups." Whilst in recent years there has been some muted acknowledgement of the growing role played by militia groups, the UNODC has ignored the close links between these militias and the Tatmadaw in Shan State, continuing to define areas in which militias operate as beyond government control.
} 
research groups, which regularly draw attention to the Tatmadaw's role in the drug trade. ${ }^{86}$ As importantly, however, it also reflects a hazy understanding of the dynamics of the drug trade in Shan State and the tendency to equate the Tatmadaw's lack of direct control over refineries and ownership of trafficked drug consignments with a lack of involvement in the drug economy as a whole.

Ever since the 1950s the drug trade has provided two interrelated but distinct ways of generating revenue: (1) from the buying, refining, and cross-border trafficking of drugs, (2) and from heavy informal taxation. Different actors dominate these income-generating mechanisms. As the respected Shan academic and former leading SSA member Chao Tzang Yawnghwe, rightly pointed out in the late 1980 s,

those in this business [of drugs] and making money are a class of apolitical people whose sole interest in life is trade and profit. The majority are Chinese whose relatives, partners, friends, organizations, finance, loyalties, interests and obligations straddle national frontiers. ${ }^{87}$

These traders and investors - some of whom have their origins in the KMT networks established in the 1950s and still have close links with armed groups in the region-generate the most income from the production and sale of heroin. Some are small-scale petty traders who engage with the drug trade alongside other legal business enterprises. Others are part of much larger cross-border networks that link drug production and refining sites in Shan State with trafficking networks in Yunnan and elsewhere in China and Southeast Asia. Over the years traders and investors have shifted their allegiance to whichever groups have proved best able to secure their access to opium and cross-border markets. In southern Shan State the investments have shifted from KMTnetworks, to the MTA, to the UWSA, and now increasingly also to militia groups with close links to the Tatmadaw.

In contrast, the income generated from taxation is a function of territorial control and has thus been the domain of armed actors across Shan State, some of whom have also had a direct share in the final product itself. Indeed, even Khun Sa, the country's most renowned drug lord, referred to himself in the 1980s, only partly disingenuously, as not the king of opium but the king of taxing opium. ${ }^{88}$ The four-month-long growing season and the difficulty of concealing fields of poppies in full bloom increase farmers' vulnerability to eradication. Paying taxes has become a way of mitigating this risk. As one farmer from Mongton township, interviewed in 2003, commented, "You pay 5,000 kyat [US\$5] per acre to the local military and nobody is going to bother you." 89 The need for buyers to access remote, insecure areas has also enabled those controlling territory to be able to tax buyers entering their territory in return for a guarantee of protection and in some cases a monopoly over the opium produced in a given area. Similarly, in an effort to avoid unwanted interference, those operating refineries and trafficking networks pay taxes in return for impunity, protection, and in some cases access to secure trade routes.

\footnotetext{
${ }^{86}$ Prominent examples of research reports which have emphasized the military's involvement with the drug trade in Shan State include: SHAN 2003 \& 2005; SHAN Drug Watch Newsletters (cf: SHAN 2007, 9-14; SHAN 2010: 812); PWO 2006 \& 2010, LNDO 2006. Despite the depth of fieldwork research in these reports (often from areas inaccessible to western researchers) many analysts have been reluctant to engage with these border-based groups on the assumption that, in light of their opposition to the Myanmar government, their findings are partial and politically motivated.

${ }^{87}$ Chao Tzang Yawnghwe 1987, 54-55.

${ }^{88}$ Interview with former MTA member. 29 April 2014. Chiang Mai.

${ }^{89}$ SHAN 2003, 32.
} 
Local Tatmadaw commanders in Shan State have used these taxation mechanisms to generate income. As one $\mathrm{Pa}-\mathrm{Oh}$ researcher explained with regards to the opium economy in Pinlaung and Pekhon townships in southern Shan state:

Almost all of these taxes are informal and likely to be ad hoc, based on the decisions made at a local level by battalion commanders. This tax can take many forms. Farmers may be taxed in order to enjoy the "right" to grow opium. This is a protection racket for it has the threat that nonpayment will lead to prosecution. They [farmers] may be taxed at harvest time in order to sell their opium. Farmers may also be taxed during eradication drives when headmen have to negotiate with those coming to eradicate the crop in order to spare their fields. The military also tax opium buyers in order to access rural communities and to traffic the drugs. These taxes may also be collected by militia groups who are given the opportunity to tax the crop in the area they control in return for paying a proportion of this tax to the Army. ${ }^{90}$

The localized nature of taxation mechanisms and military commanders' desire to conceal their interaction with the drug trade means there is little uniformity regarding how the Tatmadaw collects taxes. In some areas the Tatmadaw has collected tax directly from poppy farmers, threatening to destroy crops if taxes were not paid. This was a regular practice in the 1990s when some taxes were even paid in opium rather than cash. ${ }^{91}$ More commonly, tax collection is managed through the village headman who has to collect a designated amount of tax from the community for the local Tatmadaw camp. In some areas, taxation is indirect, as one former poppy farmer from Mongnai township explained:

We paid tax, but indirectly. The buyer would pay tax on the opium he bought from us, on our behalf. This tax was then deducted from the price that the buyer would pay to us for our crop. The buyers had to pay tax to the Burma Army. This was only once a year when the crops were sold. ${ }^{92}$

The Tatmadaw also gains from issuing "taxation rights" and "opium monopolies," which give individuals/groups the sole right to tax farmers and monopolize the purchase of opium within a given area in return for a fee. This method is an easy way for Tatmadaw battalions to convert territorial control into a means of generating income from the region's most lucrative commodity without the need to engage directly with the drug trade or to risk attack when collecting taxes in rural areas. The Myanmar state's ability to extend its military presence and to pursue "coercionintensive" 93 forms of state consolidation in Shan State has been directly reliant upon the Tatmadaw's ability to generate revenues locally. The region's illicit drug trade has thus become a vital part of the finance mechanisms underpinning the militarization of Shan State.

\subsection{Drugs and negotiated statehood: The role of militias in Shan State}

Despite the heavy presence of military personnel in Shan State, developing a military state apparatus capable of defeating the insurgency, controlling local populations, and assuring a secure environment for investors remains beyond the Tatmadaw's reach. In short, the Weberian ideal of establishing a centralized monopoly over the legitimate use of physical force has been elusive. Pressure on local military commanders to generate results has caused them to employ a diverse, pragmatic, and expedient set of strategies to pacify the borderlands. These strategies amount to a form of "negotiated statehood" that involves brokerage and coalition building rather than attempts by the state to monopolize and centralize control. Negotiated statehood is founded

\footnotetext{
${ }^{90}$ Interview with Pa-Oh researcher. 28 January 2013. Taunggyi.

${ }^{91}$ Interview with former poppy farmer from southern Shan State. 27 April 2014. Fang District, Thailand.

92 Interview with former poppy farmer from Mongnai township, Shan State. 27 April 2014. Fang District, Thailand.

${ }^{93}$ Tilly 1990.
} 
upon two closely linked processes. First, recognizing that monopolizing the means of coercion is currently beyond its reach, the Tatmadaw has sought to establish instead "coalitions of coercive force," primarily with local militias. Second, the state has attempted to co-opt powerful local elites as a way to manage the interface between the central state and local communities. As I show below, the state's engagement with the illicit opium/heroin trade has a critical role to play in operationalizing these strategies.

That local militia groups have become such an integral part of negotiated state consolidation strategies in Shan State is one of the most important but underreported developments in Myanmar's political economy over the past two decades. The use of local proxy militia groups is in itself not a new strategy: its roots lie in the legacy of the KKY initiative in the 1960s and the various anti-insurgency militias (thakasapha) that operated throughout the 1970s and 1980s. But the increase in the number of militias over the past two decades and the prioritization given to this strategy is significant. It demonstrates how the Tatmadaw's attempts to harness and empower local structures of authority by offering concessions to powerful actors in return for their support and obedience has become integral to the government's attempts to consolidate control. The origins and size of militia groups vary significantly. Many of the militias are small with fewer than fifty members. But large militias also operate across Shan State, as Table 1 shows.

Table 1: Militia groups with over one hundred men operating in Shan State

\begin{tabular}{|c|c|c|c|}
\hline Location (Township) & Name & Leader & Background \\
\hline \multicolumn{4}{|l|}{ Northern Shan State } \\
\hline Kutkhai & Kutkhai Militia & U T Khun Myat & $\begin{array}{l}\text { Long-time } \\
\text { government } \\
\text { supporter }\end{array}$ \\
\hline Kutkhai & $\begin{array}{l}\text { Tamoeng- } \\
\text { ngen } \\
\text { Militia }\end{array}$ & U Myint Lwin & $\begin{array}{l}\text { Long-time } \\
\text { government } \\
\text { supporter }\end{array}$ \\
\hline Kutkhai & Kawngkha Militia & Mahtu Naw & $\begin{array}{l}\text { Former insurgent (ex } \\
\text { KIA) }\end{array}$ \\
\hline Namkham & Panhsay Militia & Kyaw Myint & $\begin{array}{l}\text { Long-time } \\
\text { government } \\
\text { supporter }\end{array}$ \\
\hline Muse & Mongpaw Militia & U Keng Mai & $\begin{array}{l}\text { Militia formed by } \\
\text { Myanmar Army }\end{array}$ \\
\hline Lashio/Tangyan & $\begin{array}{l}\text { Manpang People's } \\
\text { Militia Force (PMF) }\end{array}$ & Bo Mon & Former MTA \\
\hline Hsipaw & Hseng Keo Militia & $\begin{array}{l}\text { Sao Loimao and Sao } \\
\text { Gaifa (TBC) }\end{array}$ & $\begin{array}{l}\text { Former insurgent } \\
\text { group (ex SSA-N) }\end{array}$ \\
\hline \multicolumn{4}{|l|}{ Southern Shan State } \\
\hline Homong & $\begin{array}{l}\text { Shan State South(SSS) } \\
\text {; Homong People's } \\
\text { Militia Force; Maha Ja } \\
\text { Wa Army }\end{array}$ & Maha Ja & Former MTA \\
\hline Namzang & Matkyan & $\begin{array}{l}\text { Lern Hsai } \\
\text { (aka U Lin Hsai) }\end{array}$ & Former MTA \\
\hline Namzang & Nayai & Zhou Sang & Former MTA \\
\hline
\end{tabular}




\begin{tabular}{|c|c|c|c|}
\hline Langkho & Langkho Militia & $\begin{array}{l}\text { Lung Yo; } \\
\text { Lung Chuay Puun; }\end{array}$ & Unknown \\
\hline \multicolumn{4}{|c|}{ Eastern Shan State } \\
\hline Mongphyak & Mongphyak PMF & Ja Seo Bo & $\begin{array}{l}\text { Long-time } \\
\text { government } \\
\text { supporter }\end{array}$ \\
\hline Nampong & $\begin{array}{l}\text { Nampong/Loi Taw } \\
\text { Khan People's Militia } \\
\text { Force }\end{array}$ & Lt. Col. Yishay & Former MTA \\
\hline Tachilek & $\begin{array}{l}\text { Mekong Border } \\
\text { Security Battalion }\end{array}$ & $\begin{array}{l}\text { Sai Awn } \\
\text { (son of Ja Seo Bo) }\end{array}$ & Lahu militia \\
\hline Tachilek & Mong Hai Militia & $\begin{array}{l}\text { Formerly Marku; } \\
\text { current leader } \\
\text { unknown }\end{array}$ & $\begin{array}{l}\text { Lahu militia } \\
\text { (had close ties to } \\
\text { Khin Nyunt) }\end{array}$ \\
\hline Monghsat & Punako & Ai Long and Ja Ngoi & Unknown \\
\hline
\end{tabular}

Note: The information provided in this table has been derived from numerous interviews conducted throughout northern, southern, and eastern Shan State and in northern Thailand with Shan, Palaung, Pa-Oh, and Lahu researchers, community-based organizations, local and international NGO staff, youth groups, representatives from ceasefire and non-ceasefire groups, and local populations. All information in the table has been obtained from more than one source, in many cases repeated by numerous informants.

Some militias have been formed specifically with the encouragement of the Tatmadaw by local strongmen whom it trusts. Kyaw Myint's Panhsay militia and Ja Seo Bo's Mongphyak militia are prominent examples, with both leaders having been government supporters during the $\mathrm{Ne}$ Win era. ${ }^{94}$ Other militias have their origins in the region's complicated insurgency politics, being composed largely of leaders and soldiers who once fought against the government. The Shan State South (SSS), Nayai, and Matkyan militias operating in southern Shan State and the Manpang militia operating around Lashio, for example, are all remnants of the MTA. ${ }^{95}$

The Tatmadaw utilize militias for several reasons. Beyond the major towns the Tatmadaw is stretched: it has extensive firepower but its morale and manpower are limited. Battalions that should have 700 soldiers often have only 100 to $200 .^{96}$ Militias fill the gap, acting at times as an expendable force that can insulate Tatmadaw soldiers from the everyday risks of insurgent attacks. In the areas around the hydropower Shweli Dam 1, in northern Shan State, the Tatmadaw and the Panhsay militia have worked together to confiscate land, relocating an estimated fifteen thousand villagers, and to securitize the dam site. ${ }^{97}$ Understanding the terrain, local languages and village leaders as they do, militias have more local knowledge than Tatmadaw battalions. By offering insurgent and ceasefire groups a chance to become local militias - with a degree of local autonomy and business opportunities - the Tatmadaw has been able to co-opt these groups, or factions of them, more effectively than if it had demanded that the groups demobilize or incorporate into the regular Army.

\footnotetext{
${ }^{94}$ Interview with Shan researcher. 26 April 2013. Chiang Mai.

${ }^{95}$ Interviews with civil society organizations: 28 January 2013, Taunggyi; 5 January 2013, Nai Soi, northern Thailand; 21 March 2013, Yangon; 14 February 2013, Chiang Mai.

${ }^{96}$ Interview with Shan researcher 21 June 2011. Chiang Mai.

${ }^{97}$ Interviews with Palaung civil society groups: 17 November 2012. Mae Sot; 17 June 2013, Lashio; See also TSYO 2011.
} 
Beyond the role they play in expanding the state's coercive reach, the militia strategy is also a means of converting powerful local elites with a proven ability to manage local populations and resources into "state agents," " enabling the central government to "reach down" into the "peripheries." 99 Kyaw Myint (Panhsay militia), U T Khun Myat (Kutkhai militia), Keng Mai (Mongpaw militia), and U Myint Lwin (Tamoeng-ngen militia), for example, were all elected as MPs in the 2010 election as representatives of the government-backed Union Solidarity and Development Party (USDP). ${ }^{100}$ The Tatmadaw evidently believes that incorporating such figures can ground state authority by blurring the distinction between local systems of government and centrally imposed forms of authority, which are still viewed as arbitrary and exploitative. These "proxy state actors" (or "extra-state" actors, in Nordstrom's terminology) have become key modalities of interaction between local and national structures of authority, illustrating how state-building processes are negotiated today in Shan State.

Once again, the state's interactions with the drug trade show how the state's consolidation strategies are operationalized. Rather than providing direct payment to militias, the Tatmadaw allows militia groups to carve out territorial enclaves across Shan State in which, alongside their counterinsurgency activities, they are free to generate income however they like. ${ }^{101}$ Some militias, especially those led by former MTA members, have had a decades-long involvement in drug trafficking, whilst others now have a privileged opportunity (together with businessmen linked to them) to become new players in the drug trade. In many drug producing areas farmers are required to sell their opium to the local militia operating there, creating localized monopolies founded upon coercive predation. Symbiotic relations between Tatmadaw units and militias have created what may be described as hierarchies of extraction: militias profit from the drug trade in return for fighting insurgency, ensuring local stability, and providing access to areas under their control. In this way, Tatmadaw battalions benefit indirectly from the drug trade by creating unofficial protection rackets that allow them to profit from their connections with the militias whilst keeping a layer of distance and subterfuge between themselves and drug profits.

Kyaw Myint's Panhsay People's militia offers a fascinating insight into the ways the drug trade has become embroiled in strategies to pacify and consolidate control over Shan State. Kyaw Myint (aka Li Yongqiang, or U Win Maung) is a long-time loyal government supporter in Namkham township, close to the China border in northern Shan State. ${ }^{102}$ In the 1980s he was the leader of a counterinsurgency militia operating in the area. In 1991 this group became known as the Panhsay People's militia. Today it has an estimated $300+$ members. ${ }^{103}$ Kyaw Myint enjoys close links with the Tatmadaw, especially former northeast regional commander Myint Hlaing, and controls a strategic area of the China-Myanmar border, including crossings on the Mao-Ruili

\footnotetext{
${ }^{98}$ Ko-Lin Chin 2009, 2.

${ }^{99}$ Wolf 1956, 1065; Woods 2011.

100 SHAN 2011, 19-24

${ }^{101}$ Interview with representatives of the Palaung State Liberation Front (PSLF). 26 December 2012. Chiang Mai; Interview with representatives of the Pa-Oh National Liberation Organisation (PNLO). 2 January 2013. Mae Hong Son; Interview with Shan researcher. 14 February 2013. Chiang Mai; Interview with Pa-Oh research group. 29 March 2013. Taunggyi.

${ }^{102}$ Interview with leading SHAN drug researcher. 26 April 2013. Chiang Mai. Interview with Palaung research group. 29 April 2013. Mae Sot.

${ }^{103}$ This figure relates to the number of men which the militia could call upon and arm. Only a smaller number of men play an active day-to-day role in the militia, with many more serving as reserves alongside their other jobs. Interview with representatives of the PSLF. 26 December 2013. Chiang Mai; Interview with Palaung research group. 29 April 2013. Mae Sot.
} 
River that forms part of the border. ${ }^{104}$ With over thirty years of proven loyalty, Kyaw Myint offers the Tatmadaw a safe pair of hands for the delegation of local authority in an area that is heavily contested. The Tatmadaw regularly uses the Panhsay People's militia in its counterinsurgency operations, notably in 2006 during the operation to capture SSA Commander Lt-Col Khun Kyaw and in recent clashes with the Ta'ang National Liberation Army (TNLA). ${ }^{105}$ Kyaw Myint, who is Lisu-Chinese, is also an influential figure in Yunnan Province. The Tatmadaw value him as a reliable source of information on cross-border political and economic developments as well as a facilitator between the military and Chinese companies seeking work in northern Shan State. ${ }^{106}$ Thanks to the impunity and protection Kyaw Myint has been given for his services his organization is now one of the largest drug producers in Shan State. He controls a large poppy-growing area centered on Panhsay, the highest hill area in Namkham, employing large numbers of laborers and using greater amounts of fertilizers and pesticides than in other poppy-growing regions in Shan State. Some farmers have reportedly migrated to the Panshay area aware that Kyaw Myint's protection reduces the risk of crop eradication. ${ }^{107}$ Kyaw Myint has also been granted permits and licenses to operate a number of other licit businesses in the area. In 2010 he was elected as an MP to the Shan State Parliament as a representative of the government's USDP, in an election campaign that promised that poppy cultivation in the area would be protected for another five years. ${ }^{108}$

\section{THE POLITICAL ECONOMY OF THE DRUG TRADE: FORTIFYING OR FRAGMENTING THE STATE?}

The illicit opium/heroin trade in Shan State has a number of intrinsic qualities that make it particularly malleable to processes of state consolidation. First, as a high value commodity, opium can be taxed heavily yet still remain profitable. This has enabled the Tatmadaw to tax the drug trade in order to finance the expansion of a military and administrative apparatus in an unruly region where the cost of such expansion has been prohibitive. The same rationale given for the involvement of insurgent groups in illicit economies - namely, to finance recruitment and maintain the welfare and morale of troops - is equally applicable to the Tatmadaw and its proxies in light of their inability to cover the costs of military expansion from the central coffers. ${ }^{109}$

Second, the illegality of drug production and trafficking has meant that the state's ability to offer impunity and protection has created a system of rents with which to build coalitions with local powerful actors who would otherwise have little incentive to cooperate with the state.

Furthermore, the illicit nature of opium/heroin creates incentives for those involved to seek ways to convert power and revenue obtained from their position in the drug trade into more secure

\footnotetext{
104 SHAN 2011, 22.

${ }^{105}$ Funded and armed by the KIA, the TNLA poses a threat to Tatmadaw authority in Namkham and neighboring Mantong township. Interview with representative of the PSLF. 26 December 2012. Chiang Mai.

106 SHAN 2011.

${ }^{107}$ Interview with Palaung civil society organisations. 15 and 17 June 2013. Lashio.

${ }^{108}$ Interview with Palaung civil society group. 17 November 2012. Mae Sot.

${ }^{109}$ The channeling of drug revenues into the legal economy throughout the 1990s, although not a focus of this article, also helped the SLORC/SPDC survive the financial stagnation of the country's economy and the impact of sanctions, whilst creating an emergent nexus of political and economic power with a vested interest in perpetuating SPDC rule. For a detailed analysis of the ways in which drug revenues were channeled into the legal economy throughout the 1990s and early 2000s see Meehan 2011, 389-96.
} 
forms of formal authority and legal economic enterprises. By straddling the interface between the illicit and licit economies the state has encouraged local strongmen to accommodate with the state: they carry out state-like functions in return for opportunities to "diversify" and potentially "graduate" out of the illicit economy. ${ }^{110}$ Access to legal business opportunities have become especially coveted in that Shan State's growing integration into regional markets offers lucrative opportunities to incorporate the area's natural resources into global commodity chains. The illegality of the drug trade has also given the state the upper hand in its coalitions with proxy state actors and this allows them to wield the perpetual threat of prosecution in order to suppress groups it views as having become too powerful or autonomous. This was the case in August 2009 when The New Light of Myanmar, the state's official mouthpiece, justified the Tatmadaw's devastating offensive against the Myanmar National Democratic Alliance Army [MNDAA]ceasefire group in the Kokang region, stating that

Kokang national race leaders stuck to dictatorship and warlord system and showed total disregard for the law by manufacturing illegal arms and ammunition and trafficking narcotic drugs on a large scale. So, the government had no choice but to take action against the offenders in accordance with the law. ${ }^{11}$

Third, the fact that opium is a diffuse rather than a point resource ${ }^{112}$ — with poppies blooming across much of Shan State- - has allowed the Tatmadaw to form alliances with militias across the region whilst adhering to its preferred strategy of proliferating power across an array of armed groups rather than concentrating power within a small number of proxy forces.

However, close analysis of the state's interaction with the opium/heroin trade reveals a number of definite limitations when gauging how these processes have fortified state control in Shan State. First, as Ken Maclean's 2008 study demonstrates, brokerage strategies have created complex and overlapping networks of "Tatmadaw field battalions, cease-fire groups, state-owned enterprises, and local entrepreneurs," 113 creating "mosaics of territorial control"114 over which the state has found it difficult to consolidate control. Indeed, as Tom Kramer has perceptively argued, the state's actions in the borderlands can be seen as effective at "managing conflict rather than resolving it." 115

The challenges this poses are exacerbated by the fact that in many cases it is in areas where the state is most dependent upon exercising authority through negotiation and coalition buildingareas where the Tatmadaw has only recently gained a foothold or where armed groups still retain influence and legitimacy - that these coalitions are likely to be at their weakest and most

\footnotetext{
${ }^{110}$ Goodhand and Mansfield 2010, 26. This study of the political economy of the drug trade in Afghanistan clearly reveals that the processes taking place in Shan State are not unique but also play out in other drug-producing regions. See also, Goodhand 2009.

${ }^{111}$ New Light of Myanmar 2009, 8. The attack on the MNDAA in the Kokang region of northern Shan State appeared to be motivated by the Tatmadaw's desire to exploit divisions within the MNDAA regarding whether is it should accept the government's demand that it become a border guard force (BGF) under the control of the Tatmadaw and to warn other groups what would happen if they rejected the BGF proposal. However, state media explicitly cited the MNDAA's involvement in the drug trade as the reason behind the Tatmadaw's offensive.

${ }^{112}$ Le Billon 2001, 200. A point resource is a resource that "is concentrated in an area and mostly includes resources exploited by extractive industries (i.e. mining)." A diffuse resource "is more widely spread and mostly includes resources exploited by productive industries over large areas (i.e. agriculture, forestry, and fisheries)."

${ }_{113}$ Maclean 2008, 141.

${ }^{114}$ Hardin 2002, ii.

${ }^{115}$ Kramer 2012, 5.
} 
unstable. The state's ability to use the drug trade to consolidate its control has, therefore, been uneven, adding further complexity to Shan State's political geography. The government's interaction with the UWSA and the National Democratic Alliance Army [NDAA], has had limited success. Although unofficial impunity and the offer of legal economic opportunities played an important role in securing ceasefire agreements and ending outright conflict, the areas close to the China border which these groups govern remained largely autonomous and have proved able to keep the central state at bay. In other parts of Shan State, however, Tatmadaw expansion and the formation of proxy militias across Shan State have increased the territorial reach of state authority by securitizing remote areas and extending control over populations and resources in these areas. The construction of the oil and gas pipelines, which tread a path through former insurgent-controlled territory, would have been unthinkable a mere two decades ago. Today they embody the very tangible consolidation of state control.

A second ambiguity lies in the contradiction between localized strategies of state consolidation and internationally accepted norms of the "proper" role of the state. This contradiction makes establishing durable and stable state-society relations through interaction with the illicit trade of opium problematic. State officials, militia groups, and farmers know that on the international stage their activities are illegal. The government's attempts to consolidate control through engagement with the drug trade, whilst avoiding international condemnation, has created instability and insecurity, fostering an environment in which official complicity, impunity, and support for the trade goes hand in hand with periodic antidrug raids and eradication programs. Such contradictory impulses will likely intensify as the government continues to strive for control over the region whilst the country's re-engagement with the West raises international expectations that the central government will reduce the flow of drugs from its borderlands. In this context, the bargaining processes surrounding the drug trade are unstable, with rules of the game that are never clear. Perpetual informality seemingly governs the coalitions that have been forged around the drug trade. This informality - and the potential it provides for plausible deniability of involvement - allows actors to navigate the complex contradictions between subnational, national, and international approaches to the drug economy. This raises critical questions about how the drug trade can continue to provide a foundation for state consolidation in Myanmar.

Finally, perhaps the greatest anomaly in the Myanmar state's relationship with the illicit opium/heroin trade lies in the fact that it further subverts the legitimacy of the state in the eyes of the region's population. The permissive environment surrounding the drug trade has, unsurprisingly, increased the supply of drugs in Shan State, with the Unodc estimating that 10 percent of heroin produced in Myanmar is now consumed within the country. ${ }^{116}$ Claims that the central government has been willing to ignore the social scourge caused by rising addiction rates, especially amongst the young, in order to facilitate the emergence of docile, ill-educated ethnic populations, may be far-fetched, but the incessant repetition of this claim during my fieldwork interviews reflects the corrosive impact that the state's interaction with the drug trade has had upon its attempts to forge popular legitimacy. The state's willingness to empower and govern through local militia groups has also created an environment of permissiveness toward the exploitation and expropriation of rural communities at the hands of these proxy authorities. Such experiences undermine the legitimacy of local authority structures, raising questions about the

\footnotetext{
${ }^{116}$ Interview with Unodc. 22 January 2013. Yangon. See PWO 2006 and 2010 for the impact of drug use on rural communities, especially the gender dynamics of growing addiction rates.
} 
extent to which they can provide stable governance and control over local populations and resources.

\section{CONCLUSION}

Contrary to the dominant paradigms concerning the relationship between illicit drugs, instability, and state fragility, the case of Shan State reveals how the opium/heroin trade has been co-opted by the Myanmar state to fortify its control in the region over the past twenty-five years. In its interaction with the drug trade, the state has established a greater degree of control over many of the gray areas of Shan State where its authority has historically been extremely weak. However, this interaction does not open a clear path for the state to centralize its control and such a teleological outlook should be avoided. Indeed, the state-drug trade nexus has instead resulted in processes of negotiated statehood, defined by brokerage, coalition-building, and the management rather than state monopolization of the means of coercion and extraction. As I have sought to show, there remains enduring relevance to Mary Callahan's warning that those seeking to decipher developments in Myanmar's borderlands must acknowledge that "these emerging political complexes are not simply unfortunate bumps in the road to peace but instead constitute intricate and evolving social systems that may continue to be adapted and sustained."117

ACKNOWLEDGMENTS: I would like to thank the seven anonymous reviewers of this article for their constructive comments. I also express my sincere gratitude to all those in Myanmar and northern Thailand who shared their insights with me about the political economy of Shan State's drug trade and the region's recent political history.

\section{References}

Abrams, Philip. 1988. Notes on the Difficulty of Studying the State (1977), Journal of Historical Sociology 1: 58-89.

Agnew, Jonathan. 2008. 'Borders on the mind: re-framing border thinking', Ethics \& Global Politics, 1.

Agnew, Jonathan and Stuart Corbridge. 1995. Mastering space: hegemony, territory and international political economy. London: Routledge.

Appadurai, Arjun. 2001. Globalization. Durham, NC: Duke University Press.

Ballentine, Karen, and Jake Sherman, eds. 2003. The political economy of armed conflict: Beyond greed and grievance. London: Lynne Reinner Publishers.

Ballentine, Karen, and Heiko Nitzschke, eds. 2005. Profiting from peace: Managing the resource dimensions of civil war. London: Lynne Reinner Publishers.

Ballve, Teo. 2011. Territory by dispossession: Decentralization, Statehood, and the Narco Land-Grab in Colombia, Paper presented at the International Conference on Global Land Grabbing, 6-8 April 2011.

Baud, Michiel and Willem van Schendel. 1997. 'Toward a comparative history of borderlands', Journal of World History, 8: 211-242.

Berdal, Mats, and David Malone, eds. 2000. Greed and grievance: Economic agendas in civil wars. London: Lynne Reinner Publishers.

${ }^{117}$ Callahan 2007a, 4. 
Boone, Catherine. 2003. Political topographies of the African state: Territorial authority and institutional choice. New York: Cambridge University Press.

Brenner, Neil. 1999. 'Beyond State-Centrism? Space, Territoriality, and Geographical Scale in Globalization Studies', Theory and Society 28(1): 39-78.

Brown, Catherine. 1999. Burma: The Political Economy of Violence, Disasters 23: 234-256.

Burchell, Graham, Colin Gordon and Peter Miller, eds. 1991. The Foucault Effect. Chicago: University of Chicago Press.

Callahan, Mary. 2007a. Political authority in Burma's ethnic minority states: Devolution, occupation, and coexistence. Washington, DC: East-West Center.

Callahan, Mary. 2007b. Of kyay-zu and kyet-zu: The military in 2006. In Skidmore and Wilson 2007.

Chao Tzang Yawnghwe. 1987. The Shan of Burma: Memoirs of a Shan exile. Singapore: Institute of Southeast Asian Studies.

Cheesman, Nick, Monique Skidmore and Trevor Wilson, eds. 2012. Myanmar's Transition Openings, Obstacles and Opportunities. Singapore: Institute of Southeast Asian Studies (ISEAS).

Chouvy, Pierre-Arnaud. 2010. Opium: Uncovering the politics of the poppy. Cambridge, Massachusetts: Harvard University Press.

Collier, Paul, Lani Elliot, Håvard Hegre, Anke Hoeffler, Marta Reyna-Quirol, and Nicholas Sambanis. 2003. Breaking the Conflict Trap. Washington, D.C.: World Bank and Oxford University Press.

Collier, Paul. 2000. Doing well out of war: An economic perspective. In Berdal and Malone 2000.

Collier, Paul, and Anke Hoeffler. 1998. On the economic causes of war, Oxford Economic Papers, 50 (4): 563-73.

Cornell, Svante. 2005. The Interaction of Narcotics and Conflict, Journal of Peace Research, 42: 6.

Di John, Jonathan. 2008. Conceptualising the Causes and Consequences of Failed States: A Critical Review of the Literature, LSE/DESTIN Crisis States Research Working Paper, 25 (Series 2).

Foucault, Michel. 1991. Governmentality. In Burchell et al 1991.

Gerth, H.H., and C. Wright Mills, eds. 2009. From Max Weber: Essays in Sociology. Oxford: Routledge.

Gibson, Richard. 2011. The Secret Army: Chiang Kai-Shek and the drug warlords of the Golden Triangle. Singapore: John Wiley and Sons (Asia).

Goodhand, Jonathan. 2008a. War, peace and the places in between: Why borderlands are central. In Pugh et al 2008 .

Goodhand, Jonathan. 2008b. Corrupting or consolidating the peace? The drugs economy and post-conflict peacebuilding in Afghanistan, International Peacekeeping, 15 (3): 405-23

Goodhand, Jonathan. 2009. Bandits, borderlands and opium wars: Afghan statebuilding viewed from the Margins, DIIS Working Paper, 26.

Goodhand, Jonathan. 2013. Epilogue: The view from the border. In Korf and Raeymaekers 2013.

Goodhand, Jonathan, and David Mansfield. 2010. Drugs and (Dis)order: A study of the opium trade, political settlements and state-making in Afghanistan, LSE/DESTIN Crisis States Research Working Paper 83 (series 2).

Grossman, Herschel. 1991. A general equilibrium model of insurrections, American Economic Review 81: 912-921. 
Hardin, Rebecca. 2002. Concessionary Politics in the Western Congo Basin: History and culture in forest use, Environmental Governance in Africa Working Papers Series 6.

Hartley, Keith and Todd Sandler, eds. 1995. Handbook of defense economics, Vol. 1. Amsterdam: NorthHolland.

Heyman, Josiah. 1999. States and illegal practices. Oxford: Berg.

Heyman, Josiah, and Alan Smart. 1999. States and illegal practices: An overview. In Heyman 1999.

Hirshleifer, Jack. 1995. Theorizing about conflict. In Hartley 1995.

Hirshleifer, Jack. 2001. The dark side of the force: Economic foundations of conflict theory. Cambridge: Cambridge University Press.

Jung, Dietrich, ed. 2002. Shadow Globalization, Ethnic Conflicts and New Wars: A political economy of intra-state war. London: Routledge.

Kalyvas, Stathis. 2006. The logic of violence in civil war. New York: Cambridge University Press.

Keen, David. 1998. The economic functions of violence in civil wars (Adelphi Paper, 320). Oxford: IISS/Oxford University Press.

Ko-lin Chin. 2009. The Golden Triangle: Inside Southeast Asia's drug trade. Ithaca and London: Cornell University Press.

Koonings, Kees and Dirk Kruijt. 2002. Political armies: The military and nation building in the age of democracy. London: Zed Books.

Korf, Benedikt, and Timothy Raeymaekers, eds. 2013. Violence on the margins: States, conflict, and borderlands. New York: Palgrave Macmillan.

Kramer, Tom. 2007. The United Wa State Party: Narco-Army of Ethnic Nationalist Party? Washington, DC: East-West Center.

Kramer, Tom. 2012. 'Ending 50 years of military rule? Prospects for peace, democracy and development in Burma', NOREF Report. Accessed at:

http://www.peacebuilding.no/var/ezflow_site/storage/original/application/e5489347b93b387299ad6e1452 aa3a15.pdf

Le Billon, Philippe. 2001. The political ecology of war: natural resources and armed conflicts, Political Geography 20: 561-584.

Lefebvre, Henri. 1991. The Production of Space. Oxford: Blackwell.

Lintner, Bertil. 1984. 'The Shans and the Shan State of Burma.' Contemporary Southeast Asia, 5 (4): 403-450.

Lintner, Bertil. 1990. The rise and fall of the Communist Party of Burma. London: Cornell University Press.

Lintner, Bertil, 1993. The politics of the drug trade in Burma, Indian Ocean Centre for Peace Studies, The University of Western Australia, Occasional Paper, 33.

Lintner, Bertil. 1999. Burma in revolt: Opium and insurgency since 1948. Chiang Mai: Silkworm Books.

Lintner, Bertil. 2012. 'Burma and Myanmar mean exactly the same thing'. Mizzima. Wednesday 11 January 2012.

Lintner, Bertil, and Michael Black. 2009. Merchants of madness: The methamphetamine explosion in the Golden Triangle. Chiang Mai: Silkworm Books. 
LNDO [Lahu National Development Organisation]. 2006. Undercurrents: Monitoring Development on Burma's Mekong: Issue 2. Chiang Mai: LNDO.

Lujala, Päivi, Nils Petter Gleditsch, and Elisabeth Gilmore. 2005. A Diamond Curse? Civil War and a Lootable Resource, The Journal of Conflict Resolution, 49(4): 538-562.

Lund, Christian. 2006. Twilight Institutions: An Introduction, Development and Change 37: 673-684.

MacLean, Ken. 2008. Sovereignty after the Entrepreneurial Turn: Mosaics of Control, Commodified Spaces, and Regulated Violence in Contemporary Burma. In Nevins and Peluso 2008.

Mann, Michael. 1984. The autonomous power of the state: its origins, mechanisms and results, European Journal of Sociology 25:185-213.

Maule, Robert Bruce. 1993. British Policy and Administration in the Federated Shan States, 1922-1942. Toronto: University of Toronto.

Maung Aung Myoe. 2009. Building the Tatmadaw: Myanmar Armed Forces since 1948. Singapore: Institute of Southeast Asian Studies.

McCoy, Alfred. 1999. Requiem for a drug lord: State and commodity in the career of Khun Sa. In Heyman 1999.

Meehan, Patrick. 2011. Drugs, insurgency and state-building in Burma: Why the drugs trade is central to Burma's changing political order, Journal of Southeast Asian Studies 42(3): 376-404.

Migdal, Joel. 2001. State in Society: Studying how states and societies transform and constitute one another. Cambridge: Cambridge University Press.

Milliken, Jeniffer, and Keith Krause. 2002. State Failure, State Collapse, and State Reconstruction: Concepts, Lessons and Strategies, Development and Change 33: 753-774.

MIMU [Myanmar Information Management Unit]. n.d. Myanmar Information Management Unit (MIMU) (no date), Planning Map for Shan State [English]: Available online at: http://www.themimu.info/download.php?file=docs/MIMU696v01_110614_Planning percent20Map percent20for percent20Shan percent20State_Eng.pdf (accessed 14 November 2013).

Naw Noreen. 2014. 'US\$1.2 billion proposed for Burma's Defence budget'., Democratic Voice of Burma, 15 January 2014.

Nevins, Joseph and Nancy Lee Peluso. 2008. Taking Southeast Asia to Market: Commodities, nature, and people in the neoliberal age. Ithaca: Cornell University Press.

New Light of Myanmar. 2009. Tatmadaw needs not only physical and mental abilities and strength but also good morale and discipline. New Light of Myanmar, Volume XVII: 240, 12th December.

Newman, David, and Anssi Paasi. 1998. Fences and neighbours in the postmodern world: boundary narratives in political geography. Progress in Human Geography 22: 186-207.

Nordstrom, Carolyn. 2000. 'Shadows and Sovereigns', Theory, Culture \& Society 17: 35-54.

North, Douglass, John Wallis, Steven Webb, and Barry Weingast. 2007. 'Limited access orders in the developing world: A new approach to the problems of development', World Bank Policy Research Working Paper, 4359.

North, Douglass, John Wallis and Barry Weingast. 2009. Violence and social orders: a conceptual framework for interpreting recorded human history. Cambridge and New York: Cambridge University Press.

Nugent, David. 1999. State and shadow state in northern Peru circa 1900: Illegal political networks and the problems of state boundaries. In Heyman 1999. 
Palaung Women's Organisation (PWO). 2006. Poisoned Flowers. Mae Sot: PWO.

Palaung Women's Organisation (PWO). 2010. Poisoned hills: Opium cultivation surges under government control in Burma. Mae Sot: PWO.

Pugh, Michael, Neil Cooper, and Mandy Turner. 2008. Whose peace? Critical perspectives on the political economy of peacebuilding. London: Palgrave.

Renard, Ronald. 1996. The Burmese connection: Illegal drugs and the making of the Golden Triangle. Boulder: Lynne Rienner Publishers.

Ross, Michael. 2004. How do natural resources influence civil war? Evidence from thirteen cases, International Organization, 58: 35-67.

Sai Aung Tun. 2009. History of the Shan State from its Origins to 1962. Bangkok: Silkworm Books.

Scott, James. 1998. Seeing like a state: How certain schemes to improve the human condition have failed. Yale: Yale University Press.

Scott, James. 2009. The art of not being governed: An anarchist history of upland Southeast Asia. New Haven: Yale University Press.

Seidman, Michael. 2002. Republic of Egos: A Social History of the Spanish Civil War. Wisconsin, University of Wisconsin Press.

Selth, Andrew. 2002. Burma's Armed Forces: Power Without Glory. Norwalk: Eastbridge.

SHAN [Shan Herald Agency for News]. 2003. Showbusiness: Rangoon's “War on Drugs” in Shan State. Chiang Mai: SHAN.

SHAN [Shan Herald Agency for News]. 2005. Hands in Glove: The Burma Army and the Drug Trade in Shan State. Chiang Mai: SHAN.

SHAN [Shan Herald Agency for News]. 2007. Shan Drug Watch. Issue 1: June 2007.

SHAN [Shan Herald Agency for News]. 2010. Shan Drug Watch. Issue 3: October 2010.

SHAN [Shan Herald Agency for News]. 2011. Shan Drug Watch 4. Chiang Mai: SHAN.

SGM [Shwe Gas Movement]. 2011a. SOLD OUT: Launch of China pipeline project unleashes abuse across Burma. Chiang Mai: SGM.

SGM [Shwe Gas Movement]. 2011b. Corridor of Power, China's Trans-Burma oil and gas pipelines. Chiang Mai: SGM.

Skidmore, Monique, and Trevor Wilson, eds. 2007. Myanmar: The State, Community and the Environment. Canberra: Asia Pacific Press.

Smith, Martin. 1991. Burma: Insurgency and the politics of ethnicity. London: Zed Books.

Smith, Martin. 2002. 'Army politics as a historical legacy: The experience of Burma. In Koonings and Kruijt 2002.

Snyder, Richard. 2006. Does lootable wealth breed disorder?: A political economy of extraction framework, Comparative Political Studies, 39: 943-968.

Steinberg, David. 2001. Burma: The State of Myanmar. Washington, D.C.: Georgetown University.

Swe, Thein, and Paul Chambers. 2011. Cashing in across the Golden Triangle: Thailand's northern border trade with China, Laos, and Myanmar. Chiang Mai: Mekong Press.

TBBC [Thai Burma Border Consortium]. 2007. Internal Displacement in Eastern Burma: 2007 survey. Mae Sot: TBBC. 
Thant Myint-U. 2006. The river of lost footsteps: Histories of Burma. London: Faber.

Tilly, Charles. 1990. Coercion, Capital, and European States, AD 990-1992 Oxford: Blackwell Publishers.

TNI [Transnational Institute]. 2009. Burma: Neither war nor peace: The future of the cease-fire agreements in Burma. Amsterdam: TNI.

TSYO [Ta'ang Students and Youth Organization]. 2011. Shweli Under Seige: Dams proceed amid war in Burma. Mae Sot: TSYO.

TSYO [Ta'ang Students and Youth Organization]. 2012, Pipeline Nightmare: Shwe Gas fuels civil war and human rights abuses in Ta'ang community in northern Burma. Mae Sot: TSYO.

Unodc [United Nation Office on Drugs and Crime]. 2010. World Drug Report 2010. New York: Unodc.

Unodc [United Nation Office on Drugs and Crime]. 2013. Transnational Organized Crime in East Asia and the Pacific: A Threat Assessment. Bangkok: Unodc.

van der Veen, Hans. 2002. The war on drugs in the creation of the new world (dis)order. In Jung 2002.

Wai Moe. 2011. 'Than Shwe Grants Himself Power to Access 'Special Funds', The Irrawaddy, $4^{\text {th }}$ March 2011.

Walton, Matthew. 2008. 'Ethnicity, Conflict and History in Burma: The Myths of Panglong', Asian Survey 48 (6): 889-910.

Weber, Max. 1919 [2004]. Politics as a Vocation. In Gerth and Wright Mills 2009.

Wolf, Eric. 1956. Aspects of Group Relations in a Complex Society: Mexico, American Anthropologist, 58 (6): 1065-1078.

Woods, Kevin. 2011. Ceasefire capitalism: military-private partnerships, resource concessions and military-state building in the Burma-China borderlands, Journal of Peasant Studies, 38: 747-770.

Zeller, Wolfgang. 2013. Get it while you can: Governance between Wars in the Uganda-South Sudan Borderland. In Korf and Raeymaekers 2013. 